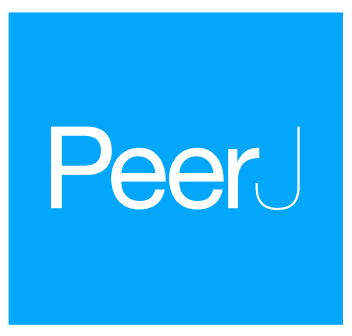

\title{
Ten years of progress and promise of induced pluripotent stem cells: historical origins, characteristics, mechanisms, limitations, and potential applications
}

\author{
Adekunle Ebenezer Omole ${ }^{1}$ and Adegbenro Omotuyi John Fakoya ${ }^{2}$ \\ ${ }^{1}$ Department of Basic Sciences, American University of Antigua College of Medicine, St. John's, \\ Antigua \\ ${ }^{2}$ Department of Anatomical Sciences, All Saints University, School of Medicine, Roseau, \\ Dominica
}

Submitted 25 October 2017

Accepted 24 January 2018

Published 11 May 2018

Corresponding authors

Adekunle Ebenezer Omole,

kunlesty@yahoo.com

Adegbenro Omotuyi John Fakoya, gbenrofakoya@gmail.com

Academic editor

Anne Fernandez

Additional Information and Declarations can be found on page 32

DOI 10.7717/peerj.4370

(c) Copyright

2018 Omole and Fakoya

Distributed under

Creative Commons CC-BY 4.0

OPEN ACCESS

\section{ABSTRACT}

The discovery of induced pluripotent stem cells (iPSCs) by Shinya Yamanaka in 2006 was heralded as a major breakthrough of the decade in stem cell research. The ability to reprogram human somatic cells to a pluripotent embryonic stem cell-like state through the ectopic expression of a combination of embryonic transcription factors was greeted with great excitement by scientists and bioethicists. The reprogramming technology offers the opportunity to generate patient-specific stem cells for modeling human diseases, drug development and screening, and individualized regenerative cell therapy. However, fundamental questions have been raised regarding the molecular mechanism of iPSCs generation, a process still poorly understood by scientists. The efficiency of reprogramming of iPSCs remains low due to the effect of various barriers to reprogramming. There is also the risk of chromosomal instability and oncogenic transformation associated with the use of viral vectors, such as retrovirus and lentivirus, which deliver the reprogramming transcription factors by integration in the host cell genome. These challenges can hinder the therapeutic prospects and promise of iPSCs and their clinical applications. Consequently, extensive studies have been done to elucidate the molecular mechanism of reprogramming and novel strategies have been identified which help to improve the efficiency of reprogramming methods and overcome the safety concerns linked with iPSC generation. Distinct barriers and enhancers of reprogramming have been elucidated, and non-integrating reprogramming methods have been reported. Here, we summarize the progress and the recent advances that have been made over the last 10 years in the iPSC field, with emphasis on the molecular mechanism of reprogramming, strategies to improve the efficiency of reprogramming, characteristics and limitations of iPSCs, and the progress made in the applications of iPSCs in the field of disease modelling, drug discovery and regenerative medicine. Additionally, this study appraises the role of genomic editing technology in the generation of healthy iPSCs.

Subjects Cell Biology, Developmental Biology, Genetics

Keywords Induced pluripotent stem cells, Reprogramming, Reprogramming factors, Embryonic stem cells, Gene editing technology, CRISPR, Cell therapy 


\section{INTRODUCTION}

The development of induced pluripotent stem cells (iPSCs) in 2006 by Shinya Yamanaka was a remarkable breakthrough that was made possible by many research findings by past and current scientists in related fields. In 1962, Sir John Gurdon achieved the first example of cellular reprogramming by reporting the generation of tadpoles from enucleated unfertilized frog egg cells that had been transplanted with the nucleus from intestinal epithelial somatic cells of tadpoles (Gurdon, 1962). This remarkable method of reprogramming somatic cells to the pluripotent embryonic state with the same genetic makeup was termed somatic cell nuclear transfer (SCNT). This discovery led to the birth of cloning. Thirty-five years later, Sir Ian Wilmut and his team used the same SCNT strategy of cellular reprogramming in the cloning of Dolly the sheep, the first mammalian to be generated by somatic cloning (Wilmut et al., 1997). These two scientific breakthroughs in somatic cloning proved that the nuclei of differentiated somatic cells contain all the necessary genetic information to generate a whole organism and that the egg cell contains the necessary factors to bring about such reprogramming. In 2001, Tada et al. (2001) further lent credence to the somatic cloning hypothesis through another novel strategy of reprogramming termed cell fusion. The cell fusion of somatic cells with embryonic stem cells (ESCs) to generate cells capable of expressing pluripotencyrelated genes showed that ESCs do contain some factors that can reprogram somatic cells (Tada et al., 2001). There are two other important landmarks-the generation of mouse ESCs cell lines in 1981 by Sir Martin Evans, Matthew Kaufman and Gail R. Martin and the subsequent generation of human ESCs in 1998 by James Thomson (Evans \& Kaufman, 1981; Martin, 1981; Thomson et al., 1998). The ESCs are developed from preimplantation embryos and are capable of generating any cell type in the body; an inherent characteristic termed pluripotency. Their discoveries shed light on the appropriate culture conditions and transcription factors necessary for the maintenance of pluripotency. The merging of all these essential historical landmarks led to the discovery of iPSCs (Fig. 1).

But why the need for iPSCs since they are pluripotent just like ESCs? Firstly, the use of ESCs is fraught with strong ethical concerns related to embryo destruction, and this has hindered its clinical application. Secondly, there are the safety concerns related to the immune rejection of the ESCs. Finally, due to its source from the embryo, ESCs are limited in supply, and this will limit broader therapeutic application. Hence, there was an urgent need for another substitute for ESCs that bypasses these important drawbacks. Indeed, the iPSCs serve as an alternative source of pluripotent stem cells with the same differentiation potential as ESCs while avoiding the ethical issues associated with the latter.

Shinya Yamanaka and Kazutoshi Takahashi developed the mouse iPSCs in 2006 through a different method of reprogramming: the use of a retrovirus to deliver into a somatic cell (mouse fibroblast), a combination of four reprogramming transcription factors, including Oct 3/4 (Octamer-binding transcription factor-3/4), Sox2 (Sex-determining region Y)-box 2, Klf4 (Kruppel Like Factor-4), and c-Myc nicknamed 


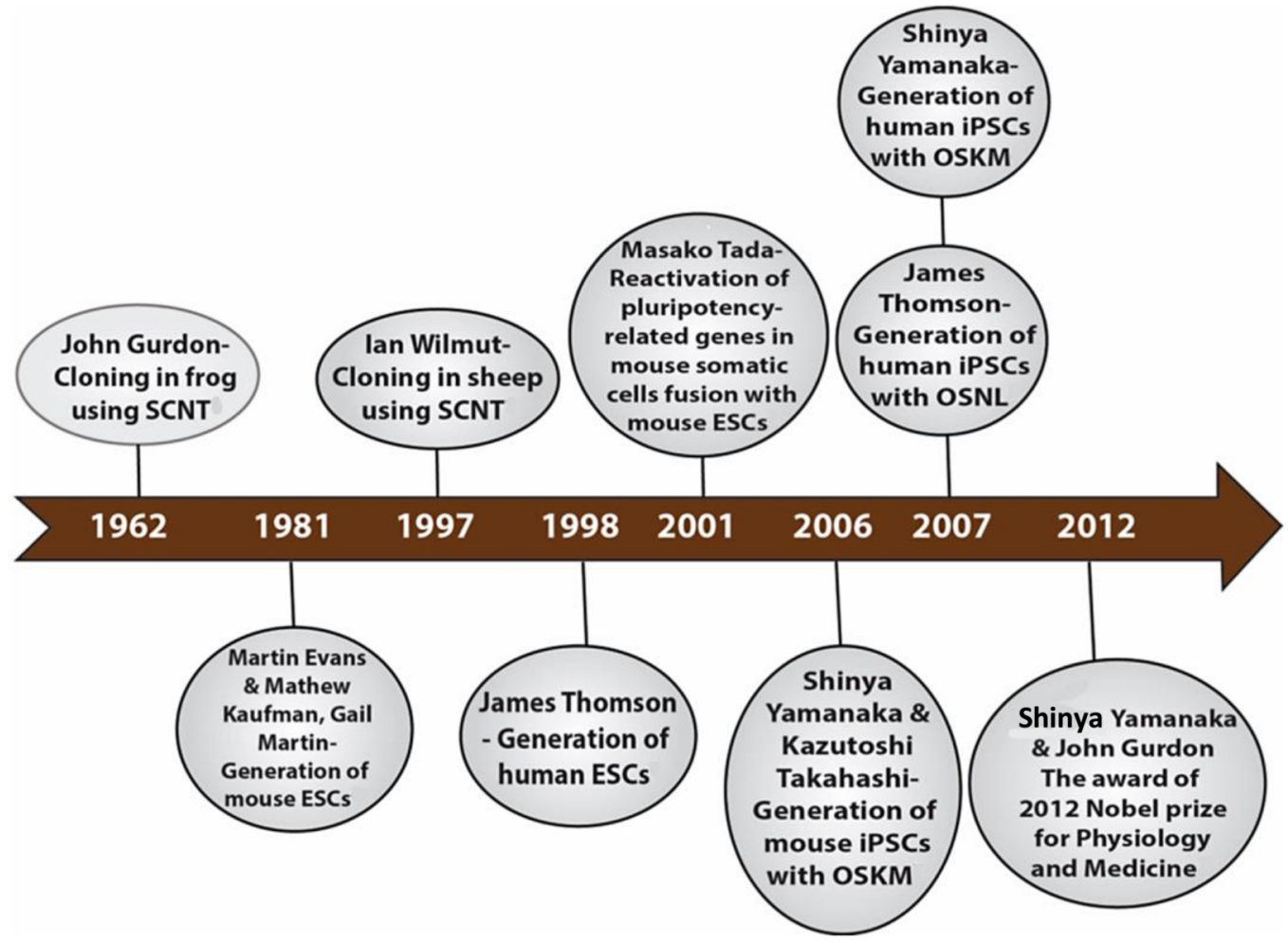

Figure 1 Historical timeline showing events that led to the development of iPSCs. Full-size $\boldsymbol{\oplus}$ DOI: $10.7717 /$ peerj.4370/fig-1

the "OSKM factors" (Takahashi \& Yamanaka, 2006). A year later in 2007, Yamanaka and his team applied the same reprogramming method for adult human fibroblast to generate human iPSCs (hiPSCs) and James Thomson's group reported the generation of the same hiPSCs though using a different delivery system, the lentivirus and a different set of four factors: Oct 3/4, Sox2, Nanog, and Lin 28 (Takahashi et al., 2007; Yu et al., 2007). For their remarkable revolutionary discoveries, Shinya Yamanaka and John B. Gurdon were awarded the 2012 Nobel prize in Physiology or Medicine (Gurdon \& Yamanaka, 2012). Like ESCs, the iPSCs have a self-renewal capability in culture and can differentiate into cell types from all three germ cell layers (ectoderm, mesoderm, and endoderm). The iPSC technology holds great promise for personalized cell-based therapy, human disease modeling, and drug development and screening. However, this technology is by no means free of its challenges. The reprogramming efficiency is low and tedious, and there is associated risk of chromosomal instability and tumorigenesis from insertional mutagenesis due to the viral vector delivery method (Takahashi \& Yamanaka, 2006; Takahashi et al., 2007; Yu et al., 2007). These drawbacks will have a significant impact on the clinical application of iPSCs.

Much progress has since been made to improve the efficiency of reprogramming and to reduce the risk associated with the technology. Novel strategies already employed to improve reprogramming include the inhibition of barriers to reprogramming, use of non-integrative delivery methods, overexpression of enhancing genes and the use 
of certain small molecules which enhanced reprogramming. Factors that influence the reprogramming process have been studied, namely, the choice of the somatic cell source, reprogramming transcription factors, delivery methods and culture conditions. Extensive research on the molecular mechanisms of reprogramming has significantly improved its efficiency.

In this review, we provide an overview of the progress made in iPSC technology in the last decade. First, we briefly define iPSCs by providing a summary of Yamanaka's key findings and the characterization of iPSCs and then summarize the current knowledge on the molecular mechanism of reprogramming, the limitations and the various strategies employed to address the drawbacks of this technology. We will then briefly discuss the potential application of iPSCs in the field of disease modeling, drug development, and regenerative medicine.

\section{METHODS}

The data for this review were obtained from Medline on OvidSP, which includes PubMed, Embase by the US National Library of Medicine as well as a search through the University of Bristol Library services.

\section{Search strategy}

A thorough search was carried out by signing into Ovid, Wolters, and Kluwer portal and "All Resources" was selected. Three separate keywords were used for the search. The first search with the keyword "induced pluripotent stem cells" yielded a total number of 5,975 publications. The second search with the keyword "cellular reprogramming" gave a total number of 3,002 publications. The third search with the keyword "transcription factors" gave a total number of 299,870 publications.

A combination of the search for "induced pluripotent stem cells" using the Boolean operator "AND" with "cellular reprogramming" and "transcription factor" yielded a total number of 200 publications. We next hand screened these 200 publications to see those that fit into the inclusion criteria for this study, and we arrived at a total of 114 publications.

Furthermore, other data were included in this review, and these were obtained from the University of Bristol Library services using the search phrase "induced pluripotent stem cells," "cellular reprogramming" and "transcription factors." The publications generated were hand screened to fit the inclusion criteria, and 61 publications were selected. Also included were relevant references from previously selected publications as well as many other recommended publications. A total of 228 articles were reviewed.

\section{Inclusion criteria}

The publications selected were thoroughly analyzed to ensure they focused on the study objectives which are on the molecular mechanism of cellular reprogramming of somatic cells into iPSCs using transcription factors and other small molecules. We included studies that focused on the barriers and enhancers of cellular reprogramming and those that emphasized the various novel strategies for enhancing the kinetics and 
efficiency of the process. Also considered were articles on the limitations and potential of iPSCs and the progress made to address such limitations. Publications that included the role of genomic editing technology in the generation of iPSCs were also considered.

\section{GENERATION OF IPSCS: A BRIEF OVERVIEW}

Briefly, iPSCs can be defined as "embryonic stem cell-like" cells derived from the reprogramming of adult somatic cells by the introduction of specific pluripotentassociated genes. Prior to the discovery of iPSCs, ESCs which are derived from the inner cell mass (ICM) of a blastocyst of pre-implantation stage embryo, was the most wellknown pluripotent stem cells. Just like ESCs, iPSCs can proliferate extensively in culture and can give rise to the three germ cell layers, namely, endoderm, mesoderm, and ectoderm.

Takahashi and Yamanaka set out to identify the genes that help in the maintenance of pluripotency in mouse ES cells. Their search led to a list of 24 candidate-reprogramming factors chosen for their links to ES-cell pluripotency. A screening method was developed to test a pool of 24 pluripotency-associated candidate factors for the ability to induce pluripotency. These genes were transduced into mouse embryonic fibroblasts (MEFs) using a retroviral delivery system. The mouse fibroblast was generated by the fusion of the mouse F-box only protein 15 (Fbxo15) gene locus with a $\beta$-galactosidase ( $\beta$-geo) cassette. The expression of $\beta$-geo is used as a reporter of Fbxo15 expression and activity, as cells expressing $\beta$-geo are resistant to the selection marker geneticin (G418). The ESC-specific Fbxo-15 locus is not expressed in normal somatic cells which are not resistant to G418 treatment. The Fbxo 15- $\beta$-geo MEFs were used to screen the pool of 24 transcription factors by transducing different combinations of the candidate genes and assessing the capability of the MEFs to survive in G418 treatment (Fig. 2). Consecutive rounds of elimination of each factor then led to the identification of a minimal core set of four genes, comprising Oct3/4, Sox2, Klf4, and c-Myc (OSKM cocktail/factors) (Takahashi \& Yamanaka, 2006). These factors were already shown to be important in early embryonic development and vital for ES cell identity (Avilion et al., 2003; Cartwright et al., 2005; Li et al., 2005; Niwa, Miyazaki \& Smith, 2000). The reprogrammed cell colonies, which were named as iPSCs, demonstrated ES cell-like morphology, express major ES cell marker genes like SSEA-1 and Nanog and formed teratomas upon injection into immunocompromised mice (Takahashi \& Yamanaka, 2006) (Table 1).

Takahashi and Yamanaka demonstrated that ectopic expression of defined transcription factors was able to reprogram mouse fibroblasts back to a pluripotent state thus circumventing the ethical concerns surrounding the use of ESCs. However, these "first generation" iPSCs demonstrated a lower level of key ES pluripotency gene expression and failed to generate adult chimeras or contribute to the germline (Takahashi \& Yamanaka, 2006). These latter characteristics suggest that the iPSCs were only partially reprogrammed. In 2007, Yamanaka and other laboratories modified the induction protocols to generate fully reprogrammed iPSCs that are competent for adult chimera and germline transmission (Wernig et al., 2007; Okita, Ichisaka \& Yamanaka, 2007; Maherali et al., 2007). The technology has also been successfully translated to human fibroblasts 


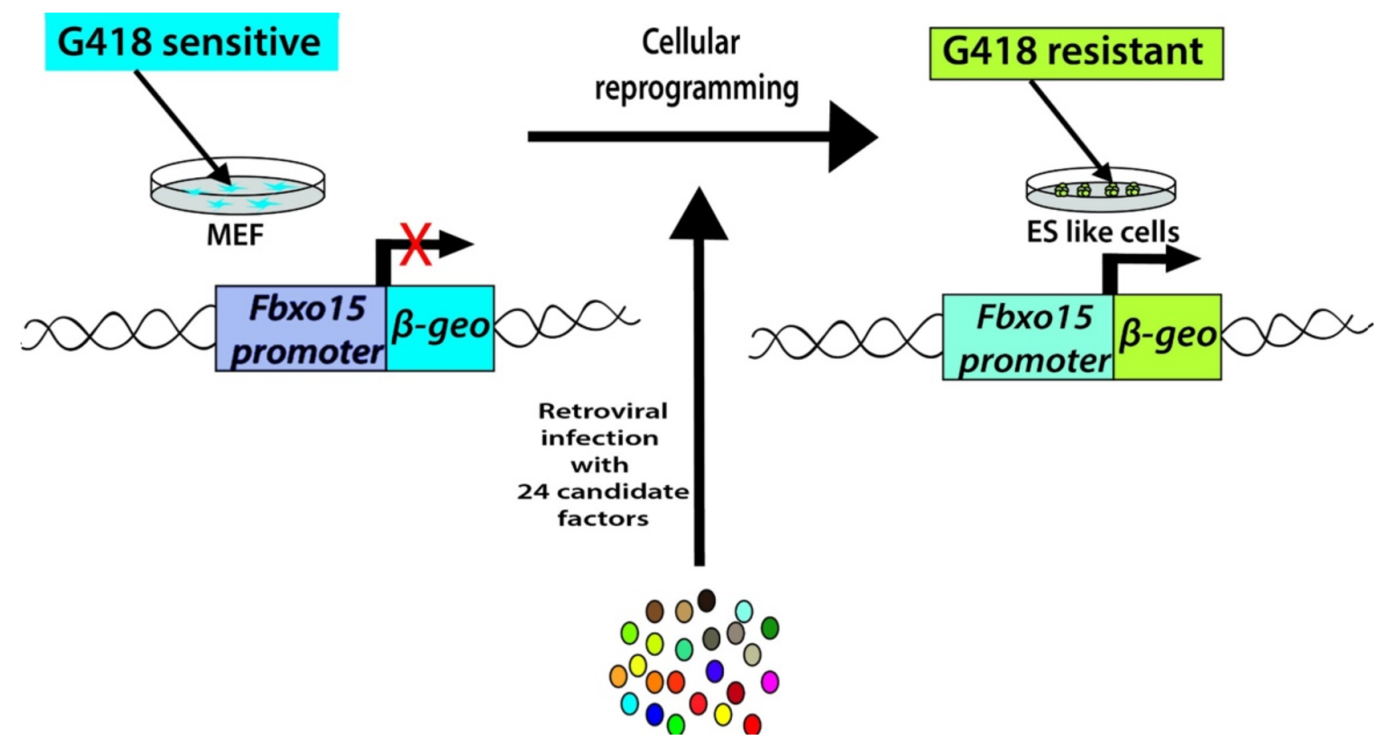

Figure 2 Generation of iPSCs from MEF cultures via 24 factors by Yamanaka.

Full-size D DOI: 10.7717/peerj.4370/fig-2

(Takahashi et al., 2007; Yu et al., 2007; Park et al., 2008a) and then to other somatic cell types, such as pancreatic $\beta$ cells (Stadtfeld, Brennand \& Hochedlinger, 2008), neural stem cells (Eminli et al., 2008; Kim et al., 2008), stomach and liver cells (Aoi et al., 2008), mature B lymphocytes (Hanna et al., 2008), melanocytes (Utikal et al., 2009a), adipose stem cells (Sun et al., 2009) and keratinocytes (Maherali et al., 2008), demonstrating the universality of cellular reprogramming. The advantages of iPSC technology are its reproducibility and simplicity, thus encouraging many laboratories to modify and improve upon the reprogramming technique. Consequently, remarkable progress has been made in the last decade in the field of iPSC technology.

\section{TECHNICAL ADVANCES AND PROGRESS IN IPSC GENERATION}

If iPSCs are to fulfill their promise (that they are viable and possibly superior substitutes for ESCs in disease modeling, drug discovery, and regenerative medicine), limitations and obstacles on the road to their clinical application need to be overcome. The initial reports of iPSC generation were inefficient ( 0.001-1\%) (Takahashi \& Yamanaka, 2006; Takahashi et al., 2007; Okita, Ichisaka \& Yamanaka, 2007; Lowry et al., 2008; Huangfu et al., 2008b), that is, on average only one out of 10,000 somatic cells formed iPSCs. The overexpression of oncogenes such as c-Myc and Klf4 during the generation of iPSCs raises safety concerns. Indeed, in the original report of germline-competent iPSCs, $20 \%$ of the offspring developed tumors attributable to the reactivation of the c-Myc transgene (Okita, Ichisaka \& Yamanaka, 2007). Furthermore, there is the risk of insertional mutagenesis due to virus-based delivery methods (Takahashi \& Yamanaka, 2006; Takahashi et al., 2007; Yu et al., 2007). Much progress has been made in the past decade to address these limitations and to improve the reprogramming technique. New methods for 


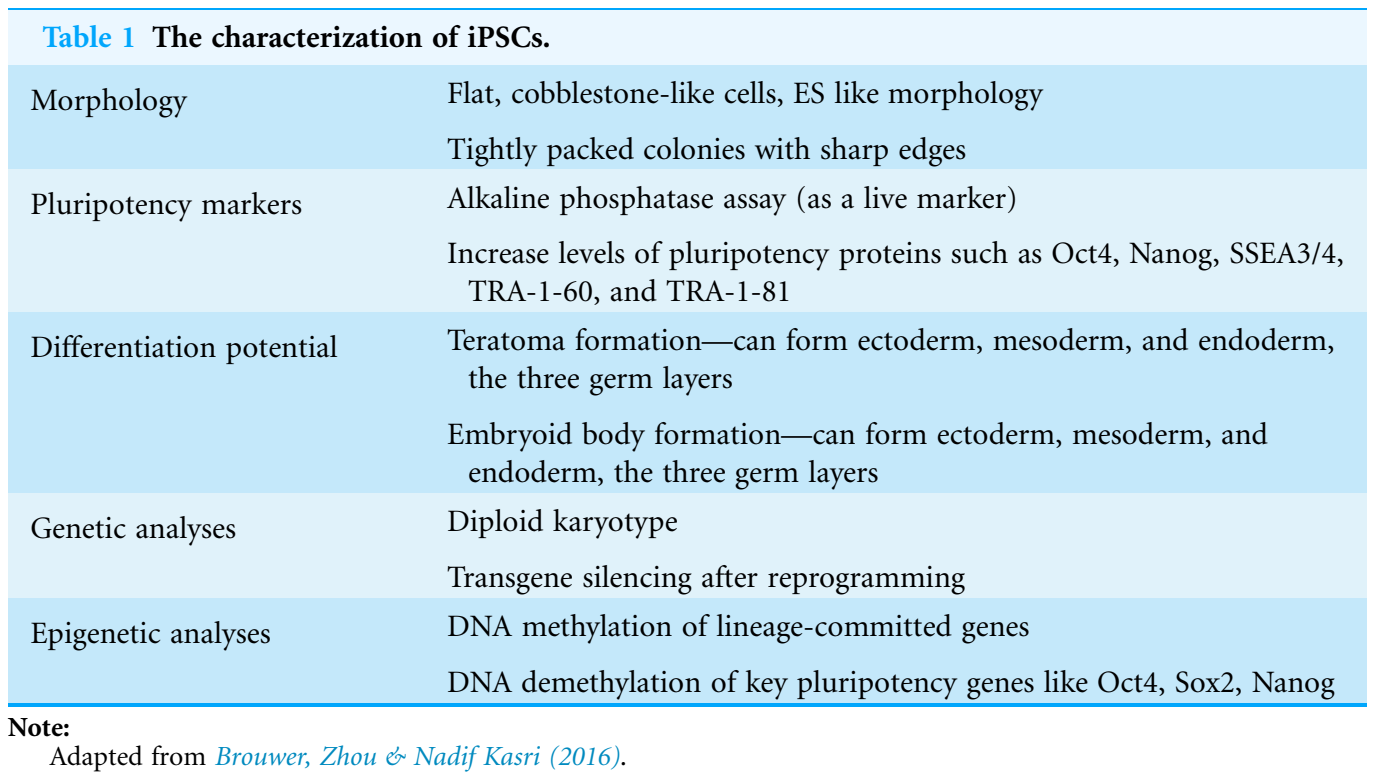

induced reprogramming have been developed. The following sections present an overview of the advancement made to improve the reprogramming technique, with emphasis on the reprogramming factors and the delivery systems for iPSC generation.

\section{Reprogramming factors}

The conventional OSKM cocktail by Yamanaka's group has been used extensively by researchers on a wide range of human somatic cells and delivery systems (Gonzalez, Boue \& Izpisua Belmonte, 2011). Thomson's group provided an alternative combination of four factors: Oct 3/4, Sox2, Nanog, and Lin 28 (OSNL) (Yu et al., 2007). The generation of iPSCs by Yamanaka's and Thomson's groups using different cocktails of transcription factors may suggest that different transcription factors activate the same reprogramming pathway by reinforcing each other's synthesis. The OSKM and OSNL reprogramming cocktails have proved efficient on a wide range of delivery systems, albeit at a variably low-efficiency rate (Gonzalez, Boue \& Izpisua Belmonte, 2011; Yakubov et al., 2010). Consequently, researchers have sought to discover new molecules that will enhance the reprogramming technique and improve its efficiency (Table 2). We will refer to these molecules as reprogramming "enhancers." Some other molecules discovered are "barriers" of reprogramming technique. So the strategy employed to increase the efficiency of reprogramming includes the inhibition of such barriers and the overexpression and administration of the enhancers.

\section{Pluripotency-associated transcription factors}

Many of the transcription factors used for reprogramming somatic cells are part of a core pluripotency circuitry. These factors are pluripotency-associated genes expressed early during embryonic development and are involved in the maintenance of pluripotency and self-renewal. The expression of other pluripotency-associated genes along with the minimal pluripotency factors (OSKM) can enhance the reprogramming efficiency or even 
Table 2 Reprogramming factors capable of reprogramming human cells.

\begin{tabular}{|c|c|c|c|c|}
\hline $\begin{array}{l}\text { Reprogramming } \\
\text { factors }\end{array}$ & Function & Affected pathway & $\begin{array}{l}\text { Effect on } \\
\text { pluripotency }\end{array}$ & References \\
\hline Oct 4 & $\begin{array}{l}\text { Maintenance of pluripotency } \\
\text { and self-renewal }\end{array}$ & $\begin{array}{l}\text { Core transcriptional } \\
\text { circuitry }\end{array}$ & + & Takahashi et al. (2007) \\
\hline Sox 2 & $\begin{array}{l}\text { Maintenance of pluripotency } \\
\text { and self-renewal }\end{array}$ & $\begin{array}{l}\text { Core transcriptional } \\
\text { circuitry }\end{array}$ & + & Takahashi et al. (2007) \\
\hline Klf4 & $\begin{array}{l}\text { Maintenance of pluripotency } \\
\text { and self-renewal }\end{array}$ & $\begin{array}{l}\text { Core transcriptional } \\
\text { circuitry }\end{array}$ & + & $\begin{array}{l}\text { Dang, Pevsner \& Yang (2000), } \\
\text { Nakatake et al. (2006) and } \\
\text { Guo et al. (2009) }\end{array}$ \\
\hline $\mathrm{c}-\mathrm{Myc}$ & $\begin{array}{l}\text { Maintenance of pluripotency } \\
\text { and self-renewal }\end{array}$ & $\begin{array}{l}\text { Core transcriptional } \\
\text { circuitry }\end{array}$ & + & Takahashi et al. (2007) \\
\hline $\operatorname{Lin} 28$ & $\begin{array}{l}\text { Maintenance of pluripotency, } \\
\text { translational enhancer, } \\
\text { inhibits let7 }\end{array}$ & $\begin{array}{l}\text { Core transcriptional } \\
\text { circuitry }\end{array}$ & + & $\begin{array}{l}\text { Yu et al. (2007) and Buganim et al. } \\
\text { (2012) }\end{array}$ \\
\hline Nanog & $\begin{array}{l}\text { Maintenance of pluripotency } \\
\text { and self-renewal }\end{array}$ & $\begin{array}{l}\text { Core transcriptional } \\
\text { circuitry }\end{array}$ & + & $\begin{array}{l}\text { Yu et al. (2007) and Buganim et al. } \\
\text { (2012) }\end{array}$ \\
\hline Sall 4 & $\begin{array}{l}\text { Maintenance of pluripotency } \\
\text { and self-renewal }\end{array}$ & $\begin{array}{l}\text { Core transcriptional } \\
\text { circuitry }\end{array}$ & + & $\begin{array}{l}\text { Tsubooka et al. (2009) and Buganim } \\
\text { et al. (2012) }\end{array}$ \\
\hline Utf1 & Maintenance of pluripotency & $\begin{array}{l}\text { Core transcriptional } \\
\text { circuitry }\end{array}$ & + & $\begin{array}{l}\text { Zhao et al. (2008) and Buganim et al. } \\
\text { (2012) }\end{array}$ \\
\hline p53 & $\begin{array}{l}\text { Induces senescence, tumor } \\
\text { suppressor }\end{array}$ & Apoptosis/cell cycle & - & $\begin{array}{l}\text { Kawamura et al. (2009), Marion et al. } \\
\text { (2009), Utikal et al. (2009b), } \\
\text { Hong et al. (2009) and Banito et al. } \\
\text { (2009) }\end{array}$ \\
\hline $\mathrm{p} 21$ & $\begin{array}{l}\text { Induces senescence, tumor } \\
\text { suppressor }\end{array}$ & Apoptosis/cell cycle & + & $\begin{array}{l}\text { Hong et al. (2009), Banito et al. (2009) } \\
\text { and Li et al. (2009a) }\end{array}$ \\
\hline MDM2 & p53 inhibitor & Apoptosis/cell cycle & + & Hong et al. (2009) \\
\hline REM2 & p53 inhibitor & Apoptosis/cell cycle & + & Edel et al. (2010) \\
\hline Cyclin D1 & $\begin{array}{l}\text { Stimulates E2F/G1-S cell cycle } \\
\text { transition }\end{array}$ & Apoptosis/cell cycle & + & Edel et al. (2010) \\
\hline SV40 large T antigen & $\begin{array}{l}\text { Inhibits p53 tumor } \\
\text { suppression }\end{array}$ & Apoptosis/cell cycle & + & Mali et al. (2008) \\
\hline DOT1L & $\begin{array}{l}\text { Histone H3K79 } \\
\text { methyltransferase }\end{array}$ & Chromatin remodeling & - & Onder et al. (2012) \\
\hline MBD3 & $\begin{array}{l}\text { Histone deacetylation, } \\
\text { chromatin remodeling }\end{array}$ & Chromatin remodeling & - & Rais et al. (2013) \\
\hline Sirt6 & $\begin{array}{l}\text { Chromatin remodeling/ } \\
\text { telomere maintenance }\end{array}$ & Chromatin remodeling & + & Sharma et al. (2013) \\
\hline RCOR2 & $\begin{array}{l}\text { Facilitates histone } \\
\text { demethylation }\end{array}$ & Chromatin remodeling & + & Yang et al. (2011) \\
\hline \multicolumn{5}{|l|}{ Non-coding RNA } \\
\hline $\operatorname{miR} 367$ & Inhibits EMT & TGF $\beta$ & + & Anokye-Danso et al. (2011) \\
\hline LincRNA-ROR & $\begin{array}{l}\text { Regulates expression of core } \\
\text { transcriptional factors }\end{array}$ & $\begin{array}{l}\text { Core transcriptional } \\
\text { circuitry }\end{array}$ & + & $\begin{array}{l}\text { Loewer et al. (2010), Wang et al. } \\
\text { (2013), Melton, Judson \& Blelloch } \\
\text { (2010) and Worringer et al. (2014) }\end{array}$ \\
\hline $\operatorname{miR} 302$ & $\begin{array}{l}\text { Inhibits EMT/stimulates oct } 4 \\
\text { expression }\end{array}$ & $\begin{array}{l}\text { TGF } \beta \text {; Core } \\
\text { transcriptional circuitry; } \\
\text { apoptosis }\end{array}$ & + & $\begin{array}{l}\text { Anokye-Danso et al. (2011), Lin et al. } \\
\text { (2010, 2011) and Subramanyam } \\
\text { et al. (2011) }\end{array}$ \\
\hline
\end{tabular}


Table 2 (continued).

\begin{tabular}{|c|c|c|c|c|}
\hline $\begin{array}{l}\text { Reprogramming } \\
\text { factors }\end{array}$ & Function & Affected pathway & $\begin{array}{l}\text { Effect on } \\
\text { pluripotency }\end{array}$ & References \\
\hline $\operatorname{miR766}$ & Inhibits Sirt6 & Chromatin remodeling & - & Sharma et al. (2013) \\
\hline $\operatorname{miR} 200 \mathrm{c}$ & Inhibits EMT/TGF $\beta$ pathway & TGF $\beta$ & + & Miyoshi et al. (2011) \\
\hline $\operatorname{miR} 369$ & Inhibits EMT/TGF $\beta$ pathway & TGF $\beta$ & + & Miyoshi et al. (2011) \\
\hline $\operatorname{miR} 372$ & Inhibits EMT/TGF $\beta$ pathway & TGF $\beta$ & + & Subramanyam et al. (2011) \\
\hline Let7 & $\begin{array}{l}\text { Regulates expression of core } \\
\text { transcriptional factors and } \\
\text { prodifferentiaion genes }\end{array}$ & $\begin{array}{l}\text { Core transcriptional } \\
\text { circuitry/TGF } \beta\end{array}$ & - & $\begin{array}{l}\text { Loewer et al. (2010), Wang et al. } \\
\text { (2013), Melton, Judson \& Blelloch } \\
\text { (2010) and Worringer et al. (2014) }\end{array}$ \\
\hline \multicolumn{5}{|l|}{ Small molecules } \\
\hline Vitamin C & $\begin{array}{l}\text { Alleviates cell senescence/ } \\
\text { antioxidant }\end{array}$ & Hypoxia response & + & $\begin{array}{l}\text { Wang et al. (2011), Esteban et al. } \\
\text { (2010) and Chung et al. (2010) }\end{array}$ \\
\hline Valproic acid & Inhibits histone deacetylases & Chromatin remodeling & + & Huangfu et al. (2008a) \\
\hline CHIR99021 & GSK3-inhibitor & PI3k; Wnt/ $\beta$-catenin & + & Li et al. (2009b) \\
\hline Parnate & $\begin{array}{l}\text { Lysine-specific demethylase } 1 \\
\text { inhibitor }\end{array}$ & Chromatin remodeling & + & Li et al. (2009b) \\
\hline BIX-01294 & $\begin{array}{l}\text { Methyltransferase G9a } \\
\text { inhibitor }\end{array}$ & Chromatin remodeling & + & $\begin{array}{l}\text { Feldman et al. (2006) and } \\
\text { Shi et al. (2008) }\end{array}$ \\
\hline 5-Azacytidine & $\begin{array}{l}\text { DNA methyltransferase } \\
\text { inhibitor }\end{array}$ & Chromatin remodeling & + & Huangfu et al. (2008a) \\
\hline Trichostatin A & Inhibits histone deacetylases & Chromatin remodeling & + & Huangfu et al. (2008a) \\
\hline
\end{tabular}

replace some of the reprogramming factors. For example, the expression of undifferentiated embryonic cell transcription factor 1 (UTF1) or sal-like protein 4 (SALL4) with OSKM/OSK, improved the reprogramming efficiency (Zhao et al., 2008; Tsubooka et al., 2009). Non-coding RNA's like LincRoR and Let7 are involved in the regulation of expression of core transcriptional factors. LincRoR is a reprogramming enhancer while Let7 acts as a barrier by blocking the activation of pluripotency factors c-Myc, Lin 28, and SALL4. Thus, Let7 inhibition and the expression of LincRoR both enhance reprogramming efficiency (Loewer et al., 2010; Wang et al., 2013; Melton, Judson \& Blelloch, 2010; Worringer et al., 2014). Nanog and Lin 28 can replace Klf4 and c-Myc respectively, and estrogen-related receptor beta (ESRR $\beta$ ) can replace Klf4 (Yu et al., 2007; Feng et al., 2009). A recent single-cell gene expression study of partially reprogrammed cells showed that SALL4, ESRR $\beta$, Nanog and Lin 28 (rather than OSKM) was enough for reprogramming fibroblasts into iPSCs, albeit with low efficiency (Buganim et al., 2012). These observations suggest that most of these enhancer genes are possibly part of the reprogramming circuitry network activated by OSKM. Consequently, a detailed analysis of the downstream targets of OSKM may help us understand the molecular mechanisms of reprogramming, thus opening the way to increasing its efficiency.

\section{Cell cycle-regulating genes}

As they move toward pluripotency, somatic cells also gain the ability to proliferate indefinitely. Not surprisingly, two of the minimal pluripotency factors, c-Myc, and Klf4, 
are oncogenes that enhance cellular proliferation. Apparently, there will be other regulators in this cell cycle pathway. The p53 tumor suppressor protein promotes senescence and inhibits growth, thus having an inhibitory effect on iPSCs generation (Kawamura et al., 2009; Marion et al., 2009; Utikal et al., 20096; Hong et al., 2009; Banito et al., 2009). Many studies have shown that p53 inhibition can greatly enhance reprogramming efficiency (Kawamura et al., 2009; Marion et al., 2009; Utikal et al., 2009b; Hong et al., 2009; Banito et al., 2009). Cell cycle-dependent kinase inhibitors like INK4A and ARF (which are linked to the p53-p21 pathway) can block iPSC reprogramming (Li et al., 2009a). Conversely, overexpression of p53 inhibitor proteins (such as SV40 large T antigen, REM2, and MDM2), increased the efficiency of reprogramming (up to 23-fold compared to OSKM alone) (Park et al., 2008a; Hong et al., 2009; Mali et al., 2008; Edel et al., 2010). So researchers have used the strategy of overexpressing reprogramming enhancers to eliminate the barriers on the road toward pluripotency.

\section{Epigenetic modifiers}

The reprogramming of somatic cells into iPSCs is characterized by epigenetic changes, from DNA methylation to histone modifications. Chromatin remodeling is a rate-limiting step in the reprogramming process, and thus researchers have studied chemical compounds that modify the epigenetic process (Huangfu et al., 2008a). For example, DNA methyltransferase inhibitor 5-azacytidine and histone deacetylase (HDAC) inhibitors (like suberoylanilide hydroxamic acid (SAHA), trichostatin A (TSA) and valproic acid (VPA)) enhanced reprogramming efficiency in MEFs (Huangfu et al., 2008a). VPA also promotes somatic cell reprogramming with Oct4 and Sox2 alone (Huangfu et al., 2008b). The combination of CHIR99021 (a GSK3 inhibitor) with Parnate (a lysine-specific demethylase one inhibitor) causes the reprogramming of human keratinocytes with only Oct4 and Klf4 (Li et al., 2009b). Similarly, G9a histone methyltransferase promotes epigenetic repression of Oct 4 during embryonic development (Feldman et al., 2006), which is why a G9a inhibitor (BIX-01294) enhances MEF reprogramming with only Oct4 and Klf4 (Shi et al., 2008). Disruptor of telomeric silencing 1-like (DOT1L) (Onder et al., 2012), methyl-CpG binding domain protein 3 (MBD3) (Rais et al., 2013), rest corepressor 1 (RCOR2) (Yang et al., 2011), sirtuin 6 (Sirt6), and miR766 (a Sirt6 inhibitor) (Sharma et al., 2013) are all involved in chromatin remodeling, thus affecting the efficiency of reprogramming when inhibited or overexpressed. Vitamin $\mathrm{C}$ improves cellular reprogramming efficiency, in part by promoting the activity of histone demethylases JHDM1A (KDM2A) and JHDM1B (KDM2B) (Wang et al., 2011), alleviating cell senescence (Esteban et al., 2010) and inducing DNA demethylation (Chung et al., 2010).

In conclusion, microRNA (miRNA) have been used to increase reprogramming efficiency. The miRNA's mostly work by inhibiting the TGF $\beta$ signaling pathway, thereby inhibiting the epithelial to mesenchymal transition (EMT). The combination of miR-291-3p, miR-294, and miR-295 with OSK cocktail promotes iPSC generation (Judson et al., 2009). More recently, miR302, miR367, miR369, miR372, and miR200c have been used either alone or in combinations to enhance the reprogramming process in 
humans by replacing the traditional OSKM nuclear factors (Anokye-Danso et al., 2011; Lin et al., 2010, 2011; Miyoshi et al., 2011; Subramanyam et al., 2011). The miRNAs can specifically target multiple pathways thus reducing the need and amount of transcription factors for reprogramming (Subramanyam et al., 2011). In the near future, miRNA-based reprogramming may provide a more effective way of cellular reprogramming than traditional nuclear factor (OSKM) methods.

\section{Delivery methods}

A number of different delivery methods have been used to introduce reprogramming factors into somatic cells (Fig. 3). The reprogramming methods can be grouped into two categories-integrative systems (involving the integration of exogenous genetic material into the host genome) and non-integrative systems (involving no integration of genetic material into the host genome). The integrative delivery methods include the use of viral vectors (retrovirus, lentivirus, and inducible lentivirus) and non-viral vectors (linear/plasmid DNA fragments and transposons). Similarly, the non-integrative delivery methods include the use of viral vectors (adenovirus and Sendai virus) and non-viral vectors (episomal DNA vectors, mRNA, and proteins). This section is focused on the reprogramming methods currently available.

\section{Integrative delivery systems}

Viral integrative vectors

Retroviruses were used for the delivery of transcription factors in the original studies on iPSC generation (Takahashi \& Yamanaka, 2006; Takahashi et al., 2007; Wernig et al., 2007; Okita, Ichisaka \& Yamanaka, 2007; Maherali et al., 2007). Retroviruses are an efficient and relatively easy form of the delivery system. They require an actively dividing somatic cell to integrate well in the genome. iPSC is considered to be fully reprogrammed only after the upregulation of endogenous pluripotency genes and the downregulation or silencing of the integrated transgene expression. Though retroviral vectors are usually silenced in ESCs (Jahner et al., 1982; Stewart et al., 1982) and iPSCs (Park et al., 2008a; Nakagawa et al., 2008), the silencing is not always efficient, and the silenced transgenes may be reactivated later on. They can integrate randomly into the host genome leading to an increased risk of insertional mutagenesis. Certainly, in the original report of germline-competent iPSCs, $\sim 20 \%$ of the offspring developed tumor attributable to the reactivation of c-Myc transgene (Okita, Ichisaka \& Yamanaka, 2007).

Lentivirus has also been successfully used for the introduction of transgenes during cellular reprogramming (Yu et al., 2007; Blelloch et al., 2007). Like retroviral vectors, lentivirus integrates into the host genome with the risk of insertional mutagenesis, and inefficient silencing and transgene reactivation are possible. Unlike retroviruses, they can integrate into both dividing and non-dividing cells. Thus iPSCs can be generated from most somatic cell types. The original studies on iPSC generation by Yamanaka involved the use of different types of retroviruses, each delivering only one type of transcription factor (Takahashi et al., 2007). This can create many uncontrollable integration events with increased risks of transgene reactivation, inefficient transgene silencing and 


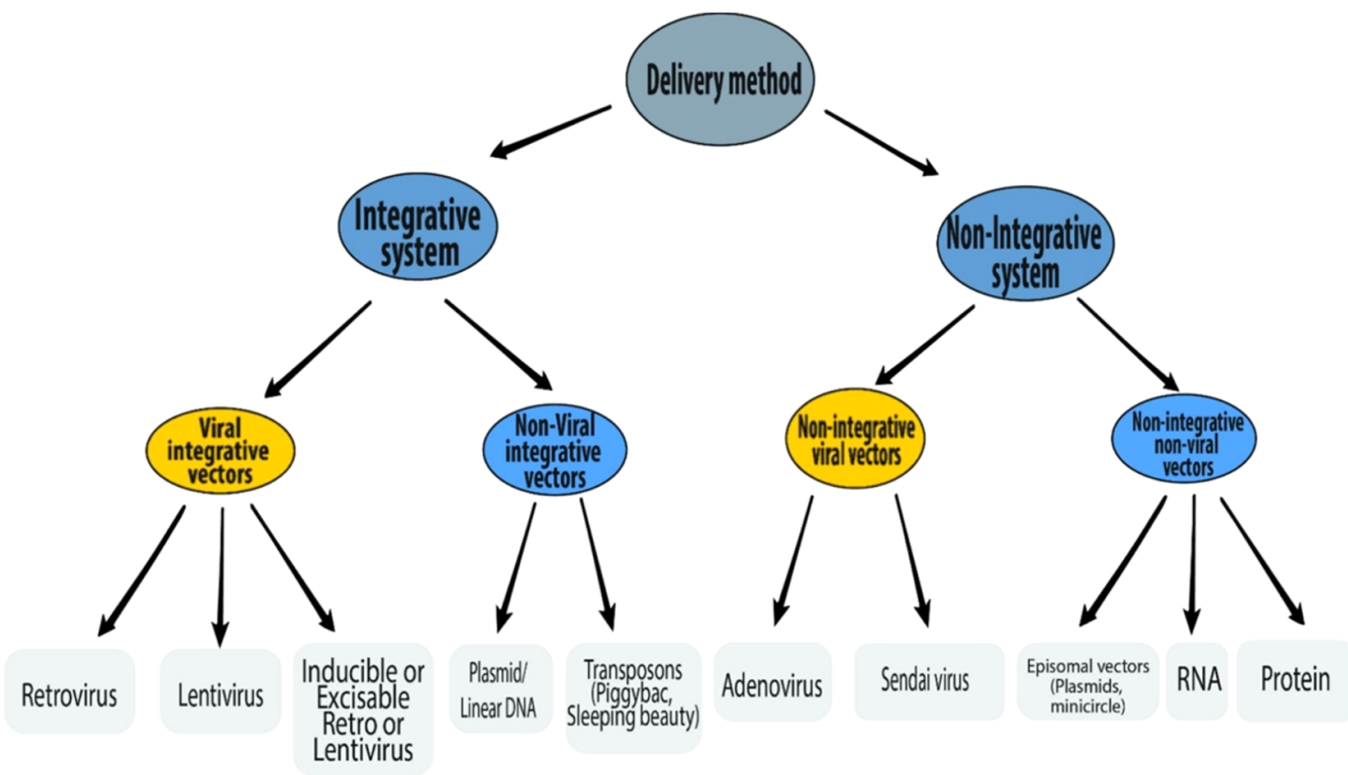

Figure 3 Schematic representation of various delivery methods of iPSC induction.

Full-size $\boldsymbol{\oplus}$ DOI: $10.7717 /$ peerj.4370/fig-3

diminished efficiency of reprogramming. The creation of polycistronic viral vectors (for retrovirus (Rodriguez-Piza et al., 2010) and lentivirus (Carey et al., 2009; Sommer et al., 2009)) allowed the expression of all reprogramming factors driven by a single promoter, with the genes separated by self-cleaving peptide sequences. This method remarkably reduces the number of genomic insertions thus improving the safety and efficiency of the reprogramming process. Moreover, the introduction of both the excisable (Cre/loxP) vector system (Soldner et al., 2009; Chang et al., 2009) and inducible (tetracycline/ doxycycline-inducible) vector system (Maherali et al., 2008; Hockemeyer et al., 2008; Wernig et al., 2008a; Staerk et al., 2010) has allowed for a better control of transgene expression thus reducing the effects of inefficient silencing and transgene reactivation.

Non-viral integrative vectors

An alternative to viral vectors is the transfection of DNA (plasmid/linear) into cells using liposomes or electroporation. Using this method, the transduction efficiency is much lower with only a few cells capturing the full set of reprogramming factors. However, the use of polycistronic vectors to express all cDNAs from a single promoter has helped to improve the reprogramming efficiency. Kaji et al. (2009) successfully generated iPSCs from mouse fibroblasts with a non-viral polycistronic vector combined with an excisable Cre/loxP system for deleting the reprogramming construct.

Transposons. Kaji et al. (2009) and Woltjen et al. (2009) applied the non-viral single vector system for the generation of human iPSCs using a piggybac (PB) transposon-based delivery system. The PB is a mobile genetic element which includes an enzyme PB transposase (that mediates gene transfer by insertion and excision). Co-transfection of a donor plasmid (transposon) with a helper plasmid expressing the transposase enzyme leads to the efficient integration of the transposon (Gonzalez, Boue \& Izpisua 
Belmonte, 2011). Once the reprogramming is achieved, the enzyme can precisely delete the transgenes without any genetic damage thus avoiding the risk of insertional mutagenesis. Drawbacks to the use of $\mathrm{PB}$ systems include the risks of integrating back into the genome, and the potential that the human genome contains endogenous $\mathrm{PB}$ transposon elements which may be acted upon by the transposase enzyme essential for the transgene excision (Newman et al., 2008; Feschotte, 2006; Grabundzija et al., 2010; Brouwer, Zhou \& Nadif Kasri, 2016). The recent introduction of another transposon, sleeping beauty (SB), has helped to overcome many of the limitations of the $\mathrm{PB}$ transposon (Grabundzija et al., 2013; Davis et al., 2013). SB integrates less compared to the $\mathrm{PB}$, and there are no SB-like elements in the human genome. However, the reprogramming efficiency of transposons is low compared to viral vectors, and their use involves multiple rounds of excision, thus increasing the risk of re-integration.

Overall, integrative delivery systems come with a risk of integration into the genome leading to insertional mutagenesis. This lack of safety may limit their therapeutic application. Non-integrative delivery systems will later address this major limitation.

\section{Non-integrative delivery systems}

Non-integrative viral vectors

Stadtfeld et al. (2008a) reported the generation of the first integration-free iPSCs from adult mouse hepatocytes using nonintegrating adenovirus. Transgene-free iPSCs were later generated from human fibroblasts by Zhou \& Freed (2009) using similar adenoviral vectors. However, the reprogramming process requires multiple viral infections, and the production of adenovirus is very labor-intensive. Most importantly, the reprogramming efficiency using adenoviruses is several orders of magnitude lower compared to lenti- or retroviruses.

Another non-integrating viral vector that has been successfully used for iPSC generation is the Sendai virus (SeV) (Fusaki et al., 2009; Seki et al., 2010; Ban et al., 2011; Nishishita et al., 2012; Ono et al., 2012; Seki, Yuasa \& Fukuda, 2012; Macarthur et al., 2012). These are very efficient in transferring genes (in the form of negative-strand singlestranded RNA) into a wide range of somatic cells (Li et al., 2000; Tokusumi et al., 2002; Inoue et al., 2003; Nakanishi \& Otsu, 2012). Although they are very effective, the viral vector's RNA replicase is very sensitive to the transgene sequence content. Additionally, because they constitutively replicate, these vectors may be difficult to eliminate from the somatic cells (Fusaki et al., 2009). A new improved Sendai virus (SeV dp) has since been developed (Nishimura et al., 2011; Kawagoe et al., 2013).

\section{Non-integrative non-viral delivery}

Episomal vectors provide another alternative to the integrative-defective viruses. Episomes are extrachromosomal DNAs capable of replicating within a cell independently of the chromosomal DNA. The reprogramming factors can be directly and transiently transfected into the somatic cells using episomal vectors as plasmids (Okita et al., 2008, 2010, 2011; Yu et al., 2009; Gonzalez et al., 2009; Cheng et al., 2012; Montserrat et al., 2011; 
Si-Tayeb et al., 2010) or as minicircle DNA (Jia et al., 2010; Narsinh et al., 2011). Unlike retro- and lentiviruses, this technique is relatively simple and easy to use and does not involve integration into the host genome. However, since episomal vector expression is only transient, they require multiple transfections. In general, their reprogramming efficiency is low, although when compared to its plasmids, the minicircle DNA has a higher transfection efficiency (probably due to it is smaller size) and a longer ectopic expression of the transgenes (due to lowered silencing mechanisms) (Chen et al., 2003; Chen, He \& Kay, 2005).

RNA delivery. iPSCs have been generated by the direct delivery of synthetic mRNA into somatic cells (Warren et al., 2010, 2012). This method has the highest reprogramming efficiency when compared with other non-integrative delivery systems. RNA has short half-lives. Thus repeated transfection is required to sustain the reprogramming process. RNA-based methods are also highly immunogenic (Brouwer, Zhou \& Nadif Kasri, 2016).

Protein delivery. Reprogramming factors can be directly delivered as recombinant proteins into somatic cells for iPSC generation (Kim et al., 2009; Zhou et al., 2009). The reprogramming efficiency is low and repeated transfection is also required to maintain the intracellular protein level for reprogramming.

Overall, integrative delivery methods have a higher reprogramming efficiency than non-integrating methods, but they are less safe due to the risk of insertional mutagenesis. Therefore, the use of non-integrating methods will appeal more for iPSC generation and use in a clinical setting.

\section{MOLECULAR MECHANISM OF INDUCED PLURIPOTENCY}

The reprogramming of somatic cells into iPSCs is a long and complex process involving the activation of ES-cell-specific transcription network, combinatorial overexpression of multiple transcription factors and epigenetic modifications. Understanding the molecular mechanisms of cellular reprogramming is critical for the generation of safe and highquality iPSCs for therapeutic applications. This section reviews the molecular mechanisms leading to induced pluripotency.

\section{The fantastic four (OSKM)}

Takahashi and Yamanaka showed that four exogenous reprogramming factors, Oct4, Sox2, Klf4, and c-Myc, all have key roles in iPSC generation (Takahashi \& Yamanaka, 2006). They discovered Oct4, Sox2, Klf4, and c-Myc were essential for iPSC generation while Nanog was dispensable (Takahashi \& Yamanaka, 2006). Though exogenous Nanog (not part of the "fantastic four") is not an essential factor and is not required to initiate the reprogramming process, it is possible that exogenous Oct 4, Sox2, and other reprogramming factors induce expression of endogenous Nanog to levels adequate to achieve full reprogramming (Jaenisch \& Young, 2008; Scheper \& Copray, 2009).

Genetic studies have shown that Oct4, Sox2, and Nanog (OSN) are key regulators of embryonic development and they are critical for pluripotency maintenance (Masui et al., 2007; Chambers et al., 2003, 2007; Avilion et al., 2003; Nichols et al., 1998; 
Mitsui et al., 2003). These factors are expressed both in pluripotent ESCs and in the ICM of blastocysts. Oct 3/4, Sox2, and Nanog knockout embryos die at the blastocyst stage and when cultured in vitro, their ESCs lose pluripotency and differentiate (Avilion et al., 2003; Nichols et al., 1998; Mitsui et al., 2003; Chambers et al., 2007). Klf4 plays key roles in cellular processes, like development, proliferation, differentiation, and apoptosis (Dang, Pevsner \& Yang, 2000). It is expressed in ESCs and can interact with Oct4-Sox2 complexes to activate certain ESCs genes (Nakatake et al., 2006). Klf4 can revert epiblast-derived stem cells to the ESC state (Guo et al., 2009). Its interaction with Oct4-Sox2 complexes and its tumor suppressor activity are thought to be important in iPSCs generation. c-Myc is a potent oncogene associated with apoptosis, cell proliferation, and cell cycle regulation (Dang et al., 2006; Lebofsky \& Walter, 2007; Patel et al., 2004). Though iPSCs can be generated without Klf4 and c-Myc, the marked reduction in the efficiency of the process greatly emphasizes their importance in cellular reprogramming.

\section{Autoregulatory loops driving pluripotency}

Experimental studies using chromatin immunoprecipitation and genome-wide localization analysis in human and murine ESCs to identify genes occupied by Oct4, Sox2, and Nanog have provided a better understanding of how these transcription factors contribute to pluripotency (Boyer et al., 2005; Loh et al., 2006). The studies reveal that Oct4, Sox2, and Nanog bind together to activate the promoters of both their genes and those of each other, hence forming an autoregulatory loop. The three factors function cooperatively to maintain their expression, thus enhancing the stability of pluripotency gene expression. Since the initial hypothesis, several other studies have provided strong verifiable evidence for the existence of the autoregulatory circuitry (Masui et al., 2007; Chew et al., 2005; Kuroda et al., 2005; Okumura-Nakanishi et al., 2005; Rodda et al., 2005).

\section{Transcriptional regulatory network}

The experimental studies also demonstrated that Oct4, Sox2, and Nanog target several hundred other ESC genes, collectively co-occupying these genes cooperatively to maintain the transcriptional regulatory network required for pluripotency (Boyer et al., 2005; Loh et al., 2006). This may explain why efficient iPSC generation seems to require the combinatorial overexpression of multiple transcription factors. The cascades of genes targeted were found to be both transcriptionally active and inactive genes (Table 3). The actively transcribed genes all have a key role in the maintenance of ESC pluripotency and self-renewal. They include various ESC transcription factors, chromatin modifying enzymes, and ESC-signal transduction genes. Conversely, the inactive genes are essentially developmental transcription factors that are silent in ESCs, whose expression is associated with cellular differentiation and lineage commitment (Boyer et al., 2005; Loh et al., 2006). Altogether, Oct4, Sox2, and Nanog appear to be master regulators of induced pluripotency by enhancing transcription of pluripotency genes, while at the same time silencing genes related to development and differentiation. Therefore, to achieve 
Table 3 The Oct4, Sox 2 and Nanog trio contributes to ES cell pluripotency by repressing genes linked to lineage commitment and activating genes involved in pluripotency.

Transcriptionally active genes

\begin{tabular}{llllll}
\hline Genes & Role of activated genes & & Genes & Role of inactivated genes \\
\hline Oct4, Sox2, Nanog & Key pluripotency genes & & Pax6, Meis1, Hoxb1, Lhx5, Otx1, Neurog1 & Ectoderm development \\
Stat3, Hesx1, Zic3, Esrrb & ES cell transcriptions factors & Hand1, Dlx5, Myf5, Onecut1 & Mesoderm development \\
Tcf3, Fgf2, Lefty2, Skil & ES cell signaling & Isl1, Atbf1 & Esx1l & Endoderm development \\
Smarcad1, Myst3, Setdb1, Jarid2 & Epigenetic regulators & & Extra-embryonic development \\
Rest & Inhibitor of neurogenesis & & \\
Rif1 & Telomere-associated protein & & \\
\hline
\end{tabular}

pluripotency, the autoregulatory loops and the transcriptional regulatory network need to be resuscitated in reprogrammed somatic cells.

\section{Epigenetic changes during iPSC reprogramming}

Induced pluripotent stem cells have a unique epigenetic signature that distinguishes them from differentiated somatic cells. Pluripotent stem cells have open, active chromatin conformations, with activating histone $\mathrm{H} 3$ lysine-4 trimethylation marks (H3K4me3), histone acetylation and hypomethylated DNA around the pluripotency genes. In contrast, lineage-commitment leads to the silencing of these pluripotency genes, with repressive H3K27me3 and H3K9me3 histone marks, hypermethylated DNA and a closed heterochromatin conformation. During the reprogramming process, the epigenetic signature of the somatic cell must be erased to adopt a stem cell-like epigenome. These epigenetic changes include chromatin remodeling, DNA demethylation of promoter regions of pluripotency genes, reactivation of the somatically silenced X chromosome and histone post-translational modifications (Takahashi et al., 2007; Wernig et al., 2007; Maherali et al., 2007; Fussner et al., 2011; Buganim, Faddah \& Jaenisch, 2013; Gonzalez \& Huangfu, 2016).

\section{DNA methylation in iPSC reprogramming}

DNA methylation is an epigenetic barrier of iPSC generation (Nishino et al., 2011; Doege et al., 2012; Gao et al., 2013). The methylation occurs at the C5 position of cytosine on the target gene promoters in mammalian somatic cells (Gonzalez \& Huangfu, 2016). Promoter DNA methylation is inversely associated with gene expression (Bird, 2002). The epigenome of iPSCs are transcriptionally active and are characterized by demethylation at the promoter regions of key pluripotency genes, like Oct4, Sox2, and Nanog. These genes are silenced by de novo DNA methylation during lineage commitment and differentiation. The methylation is established by de novo methyltransferases Dnmt3a and Dmnt3b and preserved by the maintenance methyltransferase Dnmt1 (Smith \& Meissner, 2013). During reprogramming, the methylation marks are removed from these endogenous pluripotency genes to allow for their transcription, and tissue-specific genes are hypermethylated (Gladych et al., 2015; Berdasco \& Estellar, 2011). Indeed, manipulation of the DNA and chromatin 
modifications by certain small molecules can significantly improve iPSC formation (Huangfu et al., 2008a, 2008b; Li et al., 2009b; Feldman et al., 2006) (see reprogramming factors-epigenetic modifiers). Likewise, mice lacking DNA methyltransferases remain non-viable or die within weeks ( $\mathrm{Li}$, Bestor \& Jaenisch, 1992; Okano et al., 1999). These observations show that epigenetic modifications are key to cellular differentiation, and it is reasonable to conclude that these same events have to be reversed during induced reprogramming.

\section{Histone modifications in iPSC reprogramming}

Histone modification patterns differ between pluripotent stem cells and differentiated somatic cells. The silencing of developmental genes in pluripotent stem cells is controlled remarkably. The differentiation-related genes carry "bivalent" domains (i.e., repressive histone $\mathrm{H} 3$ lysine-27 trimethylation marks (H3K27me3) and activating histone $\mathrm{H} 3$ lysine-4 trimethylation marks (H3K4me3)) in their genome loci (Bernstein et al., 2006). The H3K4me3 marks of the bivalent domains allow for transcription initiation of the developmental genes. Transcription of these genes is repressed by the action of Polycomb group, a family of proteins that regulate developmental gene expression through gene silencing by binding to repressive H3K27me3 marks. Thus, lineage-commitment genes with bivalent domains can have their expression quickly turned on or switched off via erasure of $\mathrm{H} 3 \mathrm{~K} 27 \mathrm{me} 3$ or $\mathrm{H} 3 \mathrm{~K} 4 \mathrm{me} 3$, respectively. The bivalent domains are almost exclusively found in pluripotent stem cells, and their restoration represents a vital step in the reprogramming process. During reprogramming, repressive H3K9me3 marks present on the endogenous pluripotency genes (Oct4, Sox2, and Nanog) are gradually replaced by the transcriptionally active H3K4me3 (Gladych et al., 2015). The loss of the H3K9me3 marks allows access of OSKM transgenes to their target regions thus activating the autoregulatory loop.

\section{Role of microRNAs in iPSC reprogramming}

microRNA are small non-coding RNA molecules that bind to protein-coding messenger RNA (mRNA) to regulate their degradation or translation. They regulate gene expression by post-transcriptional gene silencing (Bartel, 2004). Some miRNA promote iPSC reprogramming (see reprogramming factors-epigenetic modifiers), while others are barriers to iPSC reprogramming. Let-7 miRNAs are expressed in somatic cells and upregulated in ES cell differentiation (Roush \& Slack, 2008). Lin 28 (one of the factors used by Thomson et al. (1998) to substitute for c-Myc and Klf4) (Yu et al., 2007), promotes reprogramming by inhibiting let-7 miRNAs (Viswanathan, Daley \& Gregory, 2008).

\section{The role of reprogramming factors in IPSC reprogramming}

Following the introduction of exogenous OSKM factors into the somatic cells, exogenous Oct 4 and Sox 2 may directly induce the expression of endogenous Oct4, Sox2, and Nanog via the autoregulatory circuitry, through which they continue to maintain their expression. After that, these factors activate the pluripotent transcriptional network. Hence, the autoregulatory loop and the transcriptional network that are repressed in somatic cells, are now "resuscitated" during the reprogramming process. 
c-Myc is a vital component of active chromatin and associates with histone acetyltransferase (HAT) complexes. Thus, it facilitates an open chromatin conformation through global histone acetylation, thereby allowing Oct4 and Sox 2 to target their genomic loci (Kim et al., 2008; Scheper \& Copray, 2009; Knoepfler, Zhang \& Cheng, 2006). As a well-known oncogene, c-Myc facilitates the cancer-like transformation of somatic cells, conferring immortality and rapid proliferative potential on the pluripotent stem cells (Yamanaka, 2007). Thus, cellular division driven by c-Myc may provide somatic cells an opportunity to reset their epigenome, thereby enhancing their reprogramming (Jaenisch \& Young, 2008). As was mentioned in reprogramming factors-cell cycle regulating genes, p53 tumor suppressor proteins have inhibitory effects on iPSC generation by promoting senescence, apoptosis and cell cycle inhibition (Kawamura et al., 2009; Marion et al., 2009; Utikal et al., 2009b; Hong et al., 2009; Banito et al., 2009). Hyperexpression of c-Myc can lead to increases in p53 levels, and Klf4 can block the resulting apoptotic effect of c-Myc by suppressing p53 levels (Rowland, Bernards \& Peeper, 2005). Furthermore, Klf4 can suppress proliferation by activating p21 (a cyclin-dependent kinase inhibitor), and c-Myc can inhibit this anti-proliferative effect of Klf4 by suppressing p21 (Zhang et al., 2000; Seoane, Le \& Massague, 2002). Thus, we can conclude that c-Myc and Klf4 are mutually complementary and a balance between their expression is necessary for successful reprogramming (Scheper \& Copray, 2009; Yamanaka, 2007). The overall summary of the roles of reprogramming factors is shown in Fig. 4.

\section{Two-phase model of induced reprogramming: a gradual, stochastic process}

Several studies have shown exactly how the ectopic expression of OSKM in somatic cells induces the transition to a pluripotent state (Yamanaka, 2007; Brambrink et al., 2008; Stadtfeld et al., 2008b; Polo et al., 2012; Hansson et al., 2012; Buganim et al., 2012). Based on these studies, we now know the order of events in the reprogramming process, and we can posit that the reprogramming process consists of two broad phases: An initial, stochastic early phase (phase 1) and a more deterministic and hierarchical late phase (phase 2) (Table 4).

\section{Phase 1}

The earliest event in phase 1 is the downregulation of lineage-specific genes. This may be due to the direct repression effect of OSKM on these developmental genes or indirectly through the restoration of bivalent histone marks on the same genes (Scheper \& Copray, 2009). The next event is the upregulation of a subset of ESC-specific genes, such as alkaline phosphatase (AP), Fbx15, and SSEA1. These two events may produce a partially reprogrammed iPSC with ESC-like morphology, but can quickly revert to the differentiated state once the transgene expression is terminated. The next step is the global chromatin remodeling of the full array of pluripotency genes. This event involves the gradual unfolding of condensed heterochromatin to form an open euchromatin conformation and the removal of repressive $\mathrm{H} 3 \mathrm{~K} 9$ me3 histone marks. The latter event is brought on by the effect of c-Myc, Klf4, histones modification enzymes (acetyltransferases and demethylases) and other small molecules. The removal of the repressive histone 


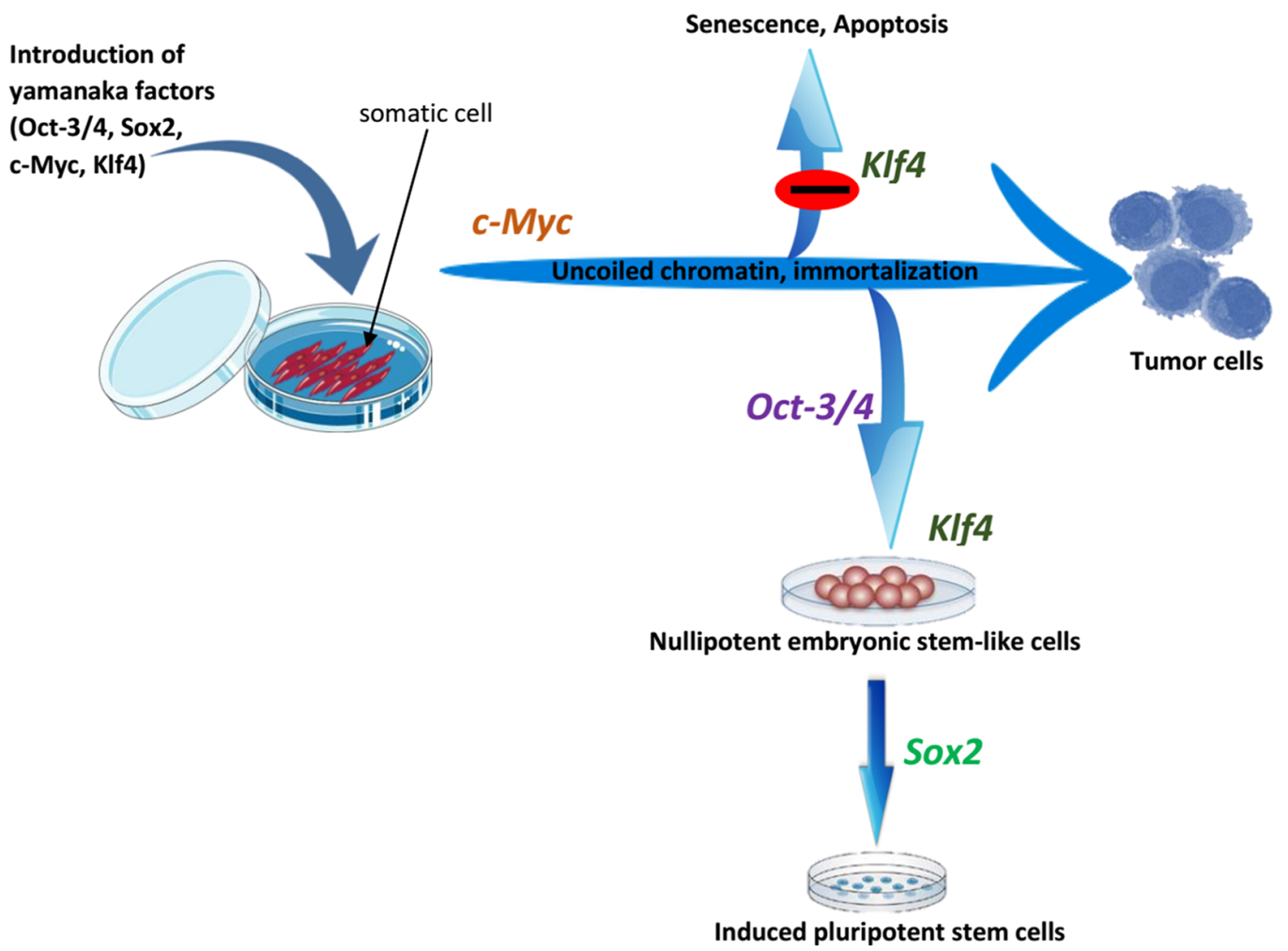

Figure 4 The roles of OSKM factors in the induction of iPSCs. Pluripotent stem cells are immortal with open and active chromatin structure. It is probable that c-Myc induce these two properties by binding to several sites on the genome and by the recruitment of multiple histone acetylase complexes. However, c-Myc also induces apoptosis and senescence and this effect may be antagonized by Klf4. Oct $3 / 4$ probably changes the cell fate from tumor cells to ES-like cells while Sox2 helps to drive pluripotency. Adapted from Yamanaka (2007).

Full-size $\emptyset$ DOI: 10.7717 /peerj.4370/fig-4

marks requires multiple rounds of cell division and explains why reactivation of endogenous Oct4, Sox2, and Nanog occurs late in the reprogramming process.

\section{Phase 2}

After the completion of global chromatin remodeling, exogenous Oct4 and Sox 2 are now able to target and activate the loci of endogenous Oct4, Sox2, and Nanog genes leading to the resuscitation of the autoregulatory loop. The completion of chromatin remodeling at other pluripotency genes further leads to the gradual restoration of the full ESC transcription network. This leads to the establishment of full-blown pluripotency, characterized by reactivation of telomerase, inactivated X chromosome and ESC signaling cascades. As the autoregulatory loops continue to self-maintain the expression of the endogenous pluripotency genes, the transgene silencing previously initiated in phase 1 comes to completion. The pluripotent state is now completely dependent on the endogenous autoregulatory circuitry.

\section{iPSC reprogramming-an inefficient process}

As mentioned above in technical advances and progress in iPSC generation, low reprogramming efficiency is one of the limitations of induced reprogramming (Takahashi \& 
Table 4 Two-phase model of induced reprogramming.

\begin{tabular}{llc} 
Order of events & Phase 1 & Phase 2 \\
\hline Step 1 & $\begin{array}{c}\text { Downregulation of lineage genes by direct } \\
\text { repression and restoration of bivalent domains }\end{array}$ & Resuscitation of autoregulatory loop \\
Step 2 & $\begin{array}{c}\text { Activation of specific ES cell genes such as AP, } \\
\text { Fbx15, and SSEA1 } \\
\text { Chromatin remodeling at pluripotency genes by } \\
\text { the unfolding of condensed chromatin and the } 3 \\
\text { removal of repressive chromatin marks }\end{array}$ & $\begin{array}{c}\text { Full reactivation of ES cell transcriptional network by } \\
\text { reactivation of telomerase and ES cell signal cascades }\end{array}$ \\
& Completion of transgene silencing
\end{tabular}

Yamanaka, 2006; Takahashi et al., 2007; Okita, Ichisaka \& Yamanaka, 2007; Lowry et al., 2008; Huangfu et al., 2008b). The elite, stochastic and deterministic models have been posited to explain the reason why only a small part of the transduced cells become pluripotent.

Elite model. This model postulates that only a few, rare, "elite" somatic cells (with stem cells characteristics) present within the somatic cell population, can be induced towards pluripotency (Yamanaka, 2009; Takahashi \& Yamanaka, 2016). In contrast to these "special" cells, differentiated cells within the population are resistant to OSKM-mediated induction (Fig. 5A). Although somatic cell populations are heterogeneous and contain stem cells (Goodell, Nguyen \& Shroyer, 2015), we now know that fully differentiated cells can be reprogrammed, thus disproving the elite model (Stadtfeld, Brennand \& Hochedlinger, 2008; Aoi et al., 2008; Hanna et al., 2008). Most of the somatic cells initiate the reprogramming process, but the majority never complete it.

Stochastic and deterministic models. Assuming all somatic cells are transduced by the OSKM, the next path to pluripotency could occur by two mechanisms: a "stochastic" manner in which iPSCs appear at different, random, unpredictable periods; or a "deterministic" manner in which iPSCs appear at a fixed, predictable period (Figs. 5B and $5 \mathrm{C})$. Both types of mechanism might be involved in the reprogramming process.

The generation of iPSCs requires a precise, limited-level expression of the transduced factors and the process involve tightly regulated levels of pluripotency genes. The specific stoichiometric balance of the OSKM factors is fundamental to successful reprogramming (Tiemann et al., 2011; Yamaguchi et al., 2011). Thus, maintaining this delicate balance appropriately can be a difficult, even rare event. Additionally, somatic cells have to overcome many barriers on the road to pluripotency (see two-phase model of induced reprogramming: a gradual, stochastic process). Furthermore, random transgene integration can result in heterogeneous transgene expression that is achieved by very few cells. The lower chance of completing these stochastic reprogramming events and the need to overcome reprogramming barriers altogether contribute to the low efficiency of reprogramming.

There are other variables that can affect the efficiency of induced reprogramming such as the choice of; reprogramming factors, delivery methods, donor cell types and culture conditions (Gonzalez, Boue \& Izpisua Belmonte, 2011; Brouwer, Zhou \& Nadif Kasri, 2016). We have already considered the effects of reprogramming factors and delivery methods 

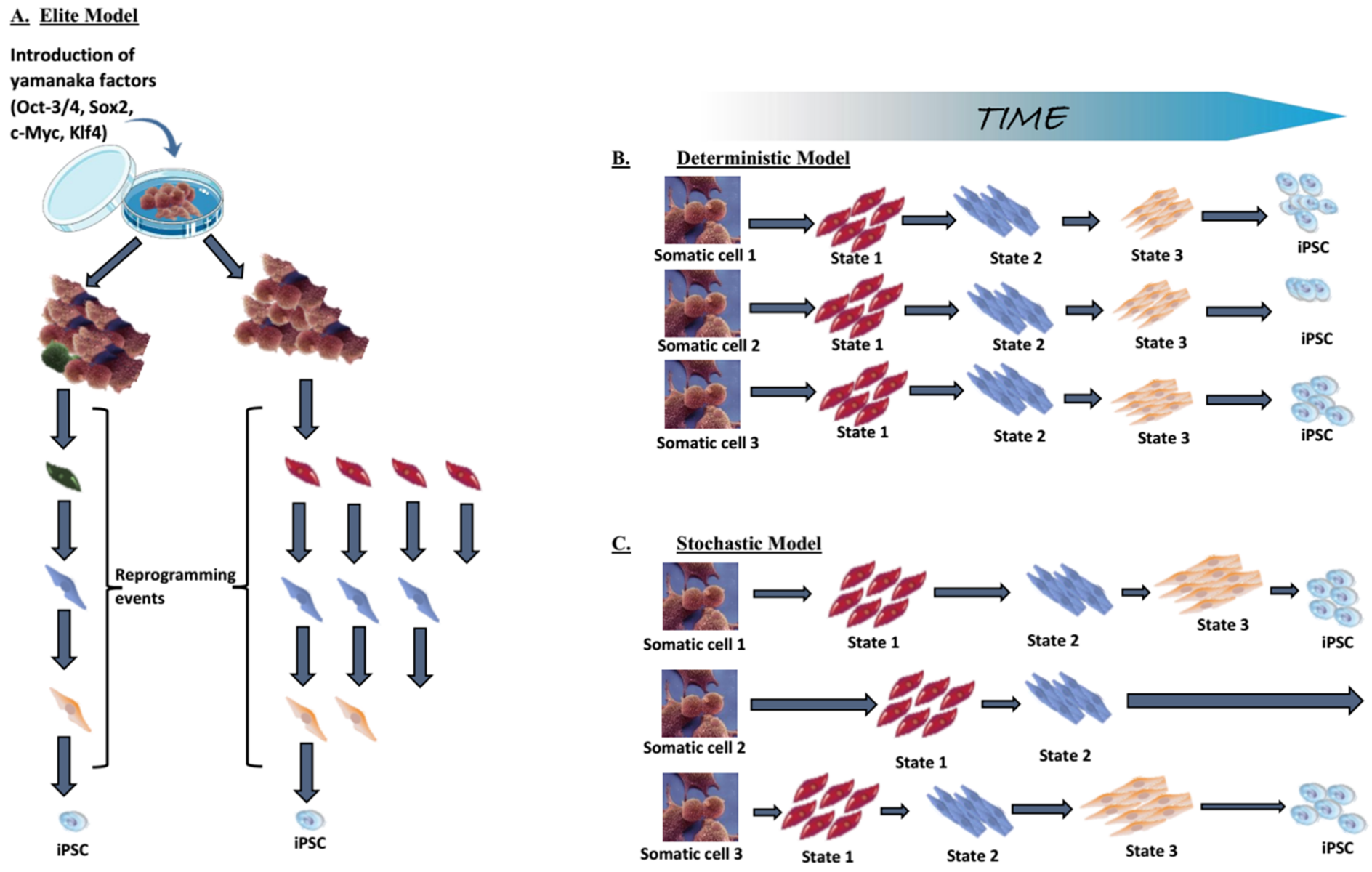

Figure 5 Mechanistic insights into transcription factor-mediated reprogramming. (A) The elite model, (B) the deterministic model, and (C) the stochastic model. Adapted from Takahashi \& Yamanaka (2016). Full-size $\operatorname{\emptyset }$ DOI: $10.7717 /$ peerj.4370/fig-5

earlier in this review. Under the same culture conditions, keratinocytes reprogramme 100 times more efficiently and two times faster than fibroblasts (Aasen et al., 2008). Haematopoetic stem cells generate iPSC colonies 300 times more than B and T cells, suggesting that the differentiation status of the donor cell type is important (Eminli et al., 2009). Hypoxic culture conditions $\left(5 \% \mathrm{O}_{2}\right)$ greatly enhances reprogramming efficiency in mouse and human cells (Yoshida et al., 2009). Taken together, donor cell types and culture conditions can modulate reprogramming efficiencies.

\section{iPSCs VERSUS ESCs}

Are iPSCs different from ESCs? Some recent comprehensive studies reveal only a few differences in global gene expression and DNA methylation patterns, which were more obvious in early passages of iPSCs (Bock et al., 2011; Guenther et al., 2010; Newman \& Cooper, 2010). However, comparison studies with relatively smaller cell clones of iPSCs and ESCs revealed more significant differences in either gene expression or DNA methylation patterns (Chin et al., 2009; Marchetto et al., 2009; Lister et al., 2011). Some of the differences were attributed to differential activation of promoters by pluripotency 
Table 5 Advantages and limitations of iPSCs technology.

\begin{tabular}{ll} 
Advantages & Limitations \\
\hline $\begin{array}{l}\text { Eliminates ethical issues and religious } \\
\text { concerns associated with ESCs use }\end{array}$ & $\begin{array}{c}\text { Efficiency of reprogramming is generally low } \\
\text { (Takahashi \& Yamanaka, 2006; Takahashi et al., }\end{array}$ \\
$\begin{array}{l}\text { Risk of immune rejection is reduced } \\
\text { (Guha et al., 2013) }\end{array}$ & Tumorigenesis (Okita, Ichisaka \& Yamanaka, 2007) \\
$\begin{array}{l}\text { Donor cell is easily and non-invasively } \\
\text { obtained, no embryo destruction }\end{array}$ & Risk of insertional mutagenesis from virus based \\
& delivery methods (Takahashi \& Yamanaka, 2006; \\
& Takahashi et al., 2007; Yu et al., 2007; Okita, \\
Accessible to large number of patients, & Ichisaka \& Yamanaka, 2007) \\
unlike ESCs limited by ethical concerns & Increased chances of development of diseases due to \\
& factors used (Hochedlinger et al., 2005; Park et al., \\
Personalization of treatment with & 2008b; Ghaleb et al., 2005; Kuttler \& Mai, 2006) \\
patient-specific stem cells and drugs & Very early days in this field, more basic research \\
(Chun, Byun \& Lee, 2011) & are needed \\
Use for disease modelling-they carry the & Complex and polygenic diseases are difficult to \\
same disease-causing factor as the patient & be modeled \\
High-throughput screening for drugs and & High costs associated with production and \\
toxicity prediction ( Wobus \& Loser, 2011; & characterization of each cell line \\
Choi et al., 2013) &
\end{tabular}

factors and variables such as the exogenous factor combinations, culture conditions, and delivery methods. Altogether, these studies have conflicting conclusions. Thus the answer to the question raised above is not straightforward. One study revealed a similarity in DNA methylation patterns between the iPSCs and the donor somatic cells, suggesting that iPSCs have a residual epigenetic "memory" marks (Kim et al., 2010a, 2010b). Even among ESC populations, there exist epigenetic heterogeneity and variable differentiation potential (Martinez et al., 2012; Osafune et al., 2008). Thus, the current consensus is that iPSCs and ESCs are neither identical or distinct, but are overlapping cell populations with genetic and epigenetic differences that reflect their origins. Further experiments are essential to ascertain if these noticeable differences have any impact on the potential therapeutic utility of iPSCs.

Though iPSCs offer many advantages when compared with ESCs, there are some limitations associated with iPSCs as well. Table 5 shows the advantages and limitations of the iPSC technology when compared to ESCs.

\section{POTENTIAL APPLICATIONS OF IPSCs}

The iPSC technology offers the opportunity to generate disease-specific and patientspecific iPSCs for modeling human diseases, drug development and screening, and individualized regenerative cell therapy. These three concepts are illustrated in Fig. 6 and are discussed in this section. 


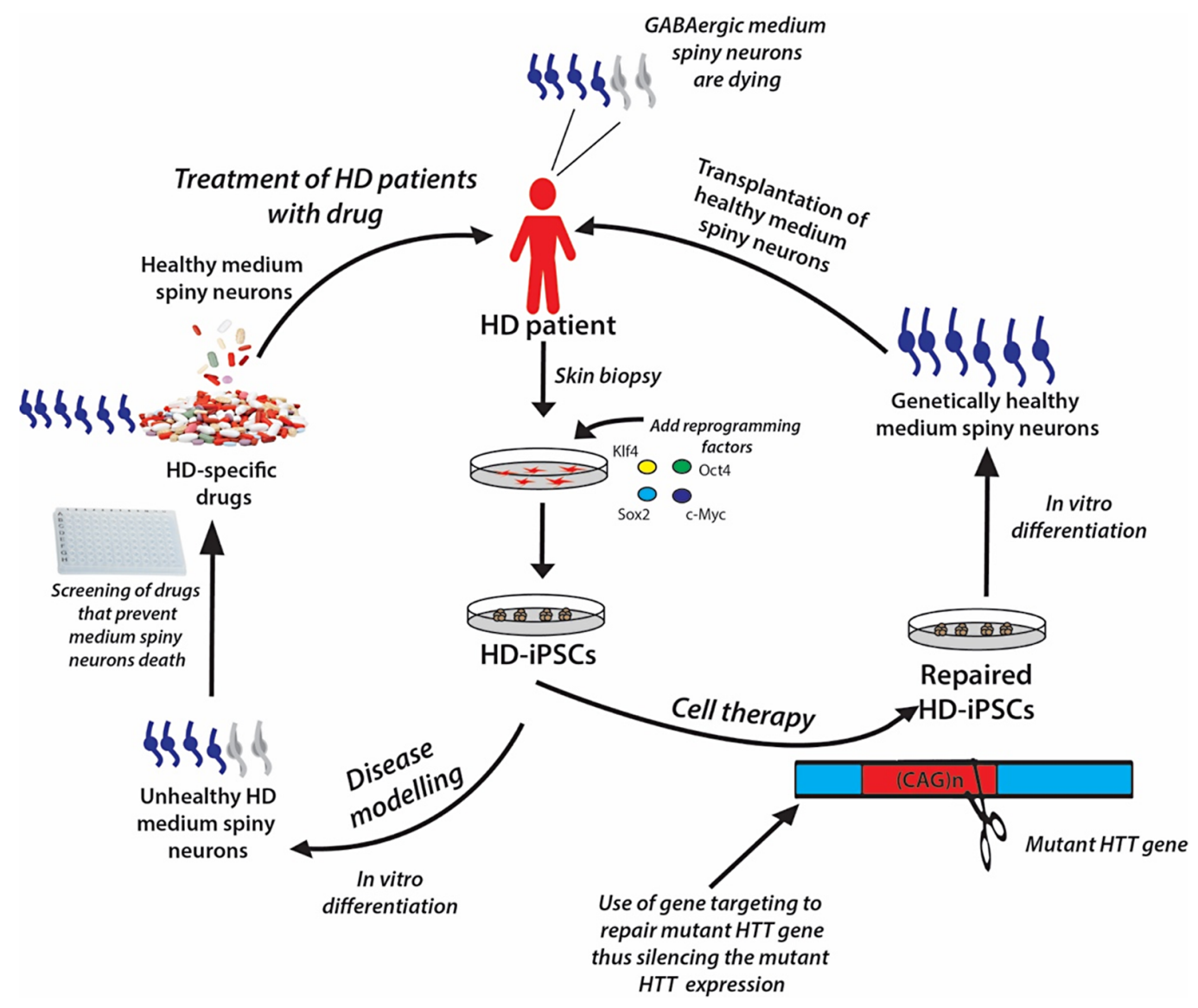

Figure 6 A schematic showing the potential applications of human iPSC technology for disease modelling, drug discovery and cell therapy using Huntington's disease (HD) as an example. In HD patients, there is progressive loss of striatal GABAergic medium spiny neurons (MSNs). HD-specific iPSCs generated by cellular reprogramming can be differentiated into striatal MSNs in order to establish an in vitro model of the disease, and potential drugs can be screened leading to discovery of novel drugs that will prevent the degenerative process. Alternatively, if known, the disease-causing mutation (i.e., mutant HTT gene) could be repaired in iPSCs by gene targeting prior to their differentiation into healthy MSNs, followed by transplantation into the patient's brain.

Full-size 0 DOI: 10.7717/peerj.4370/fig-6

\section{Disease modeling}

Genetically matched iPSC lines can be generated in unlimited quantities from patients afflicted with diseases of known or unknown causes. These cells can be differentiated in vitro into the affected cell types, thus recapitulating the "disease in a Petri dish" model. The differentiated, specialized cells or disease models offer the opportunity to gain mechanistic insights into the disease and to use the cells to identify novel disease-specific drugs to treat the disorder; for example, drugs to prevent the death of medium spiny neurons in patients suffering from Huntington's disease (Fig. 6). The ability of iPSCs to proliferate extensively in culture and differentiate into all types of cells in the human body ensures that they can be used as disease models to study many diseases. Certainly, many studies have demonstrated the generation of iPSC lines from patients with various genetically inherited and sporadic diseases (Table 6) (Wu \& Hochedlinger, 2011). These in vitro studies give the first proof of principle that disease modeling using iPSC technology 


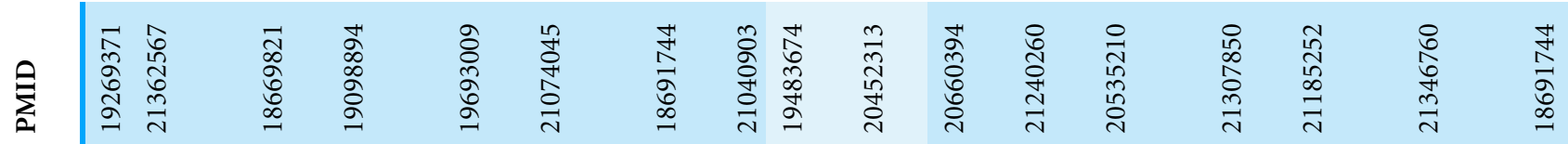

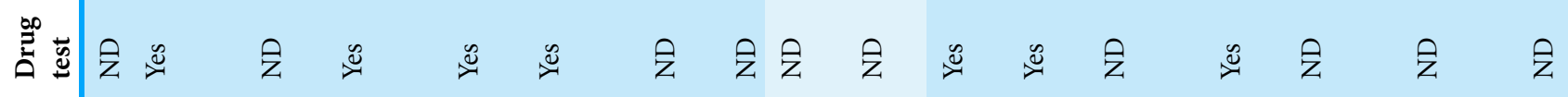



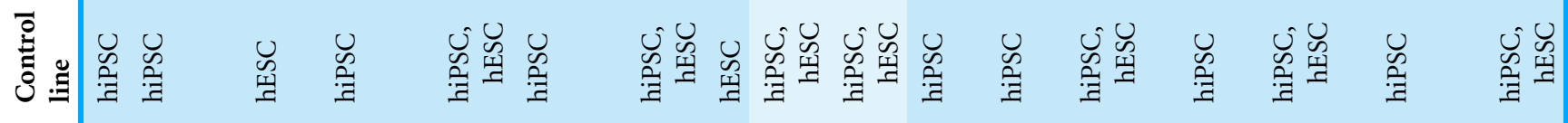

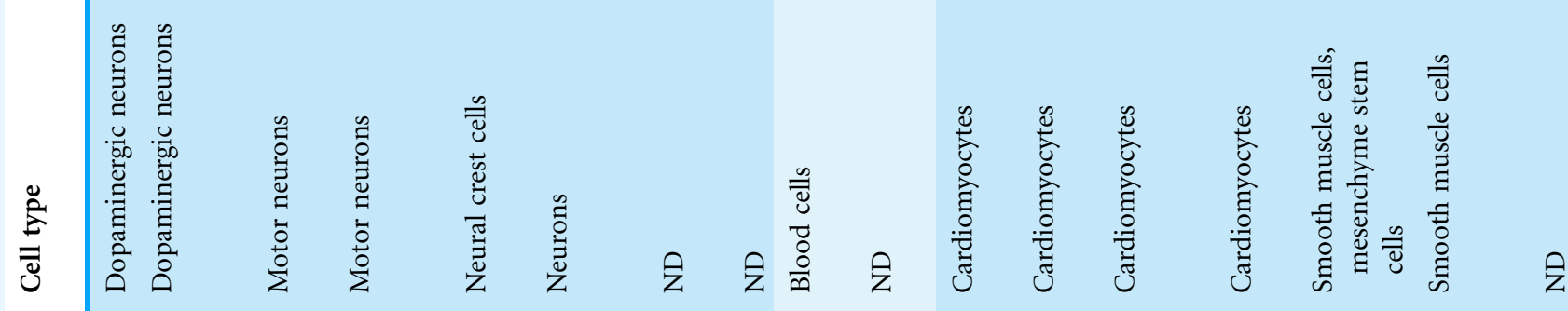
爰馀 กิ

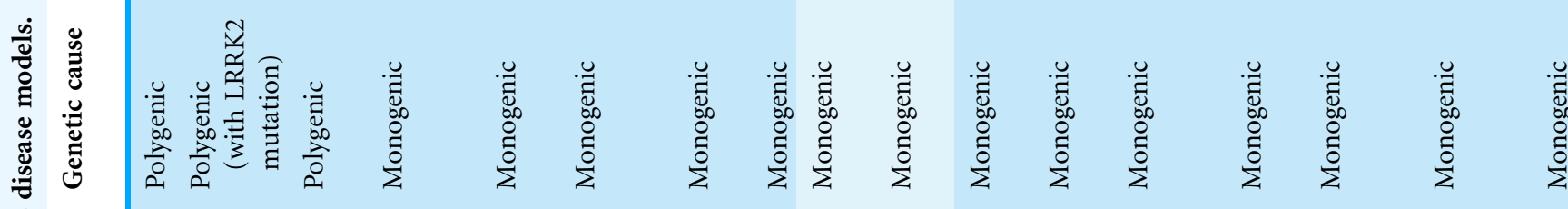
:

焉

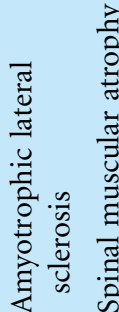

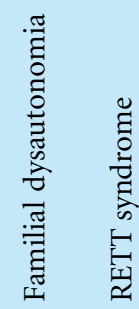

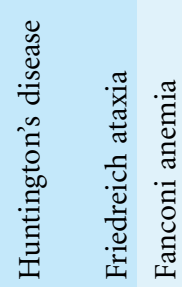

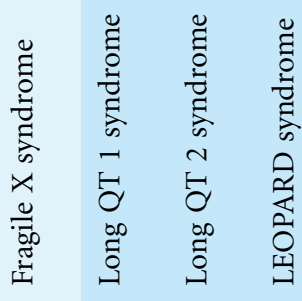

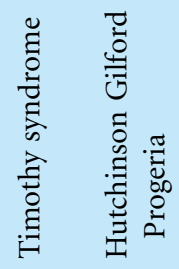




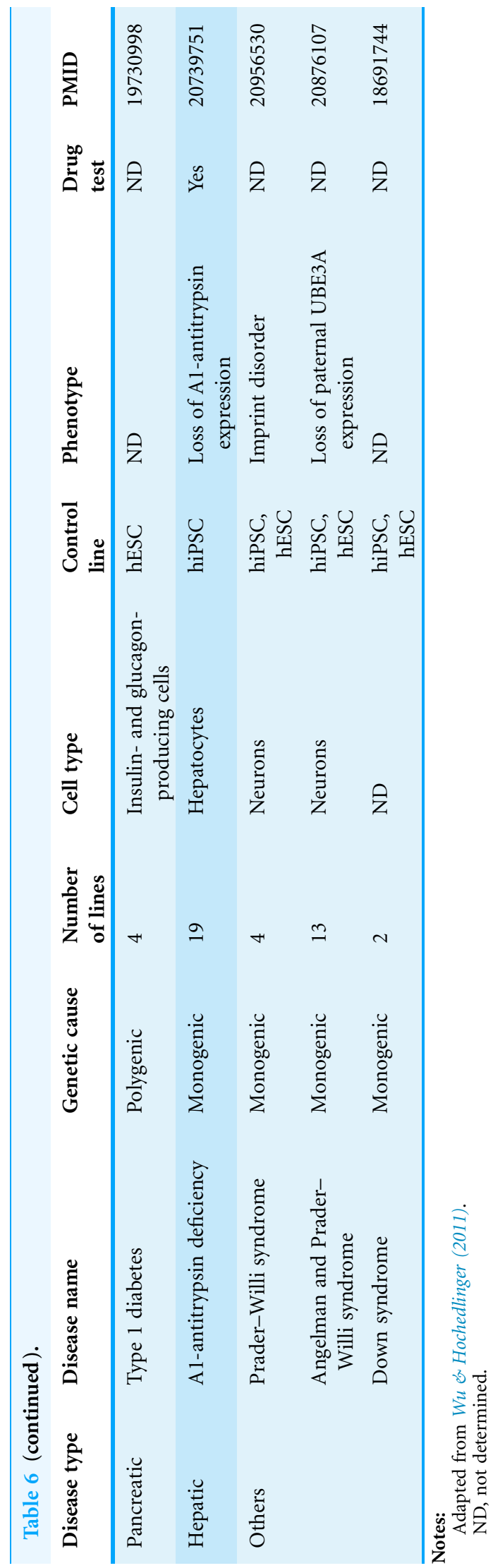


is a viable option. However, the aim of disease modeling is to understand the molecular mechanism of diseases, with the ultimate goal of developing drugs for their treatment.

\section{Drug development and cytotoxicity studies}

Lee et al. (2009) utilized iPSCs to show disease modeling and drug screening for familial dysautonomia, a rare genetic disorder of the peripheral nervous system (Table 6). The generated familial dysautonomia-iPSCs were screened with multiple compounds, and the authors revealed that a plant hormone, kinetin, can partly normalize the disease phenotype (Lee et al., 2009). Loss of neurons following in vitro differentiation of spinal muscular atrophy-iPSCs was ameliorated by exposure to experimental drugs (Ebert et al., 2009). These studies and many others (see Table 6) show that iPSCs can facilitate drug screening and discovery. Indeed, several clinical drug candidates have been derived from iPSC studies and are currently in clinical trials (Bright et al., 2015; Naryshkin et al., 2014; Mullard, 2015; McNeish et al., 2015). iPSCs are also used for testing for the toxic and non-toxic effect of therapeutic drugs. Itzhaki and colleagues used long QT 2 syndrome cardiomyocytes-iPSCs to test the potency and efficacy of existing and new pharmacological drugs and to assess the cardiotoxic effects and safe dose levels of drugs (Itzhaki et al., 2011). As a powerful tool for disease models, drug discovery and cytotoxicity studies, iPSCs offer more advantages over animal models and clinical testing. Animal models do not perfectly mirror the true human disease phenotype, and iPSCs toxicity models are less expensive and save time when compared with conventional testing systems. Additionally, a different response to drug toxicity in animals, due to species differences, could prevent the recapitulation of the full human disease phenotype.

\section{Regenerative medicine}

The iPSC technology offers an exciting opportunity for generating patient-specific stem cells for autologous transplantation. In regenerative medicine, the stem cells are used to promote endogenous regenerative repair or to replace injured tissues after cellular transplantation. The clinical translation of iPSC-based cell therapy is no longer futuristic, as the dream has now been realized. Two ground-breaking preclinical studies provided a proof-of-concept that led to the realization of this dream. In 2007, Jaenisch and colleagues used homologous recombination (gene targeting method) to repair the disease-causing mutations in iPSCs generated from a humanized mouse model of sickle cell anemia (SCA) (Hanna et al., 2007). The repaired SCA-iPSCs were differentiated into hematopoietic progenitor cells and subsequently transplanted into the affected transgenic mice. This resulted in the rescue and correction of the disease phenotype. The following year, Wernig et al. (2008b) (from Jaenisch's research group) reported an improvement in the dopaminergic function and behavioral symptoms in a rat model of Parkinson's disease, after the transplantation of iPSC-derived dopaminergic neurons. These two successful iPSC-based cell therapies spurred the stem cell research community into exploring iPSCs therapy in humans. The first clinical trial using human iPSC was initiated in 2014 by transplanting human iPSC-derived retinal pigment epithelial (RPE) cells to treat macular degeneration (Kimbrel \& Lanza, 2015). The progression of the 
macular degeneration was halted in the first patient, with improved vision (Scudellari, 2016). However, the trial was placed on hold due to the discovery of mutations in the iPSCs of the second patient (Kimbrel \& Lanza, 2015). The researchers at RIKEN institute are hoping to resume the study using HLA-matched allogeneic iPSCs (Trounson \& DeWitt, 2016; Cell Stem Cell Editorial Team, 2016).

The recent advances in genome editing technology now allow for the introduction of genetic changes into iPSCs in a site-specific manner. We can now repair disease-causing gene mutations in patient-derived iPSCs, thus generating genetically healthy human iPSCs lines for iPSC-based cell therapy (see Fig. 6). Similarly, we can also introduce specific mutations into non-diseased iPSCs, and generate genetically matched isogenic iPSC lines that mimic the true pathology of the disease of interest, to be used for human iPSC-based disease models. Gene editing technologies like zinc-finger nucleases (ZFN) (Hockemeyer et al., 2009; Zou et al., 2009), transcription activator-like effector nucleases (TALENS) (Christian et al., 2010; Hockemeyer et al., 2011; Sanjana et al., 2012), and CRISPR-Cas9 (Cong et al., 2013; Perez-Pinera et al., 2013; Shalem et al., 2014; Jinek et al., 2012) technology have greatly improved the efficiency of gene editing in both human ESCs and iPSCs via DNA double-stranded breaks at the site of gene alteration. The combination of human iPSC platform with gene editing technologies can make iPSC-based cell therapy a more powerful and viable stem cell therapy option. The following section presents an in-depth analysis regarding gene editing technology in iPSCs generation.

\section{GENOME EDITING TECHNOLOGY IN IPSCS GENERATION}

Induced pluripotent stem cells have been indisputably proven to be a discovery that will transform medicine with respect to understanding the genetic etiology of diseases while equally providing the much needed genetic therapies. Its current combination with genome editing has further enhanced the diagnostic and therapeutic power of the iPSCs (Hotta \& Yamanaka, 2015). Several methods have been used in the past to genetically target pluripotent stem cells. The process of gene targeting means modifying a specific genomic locus on a host DNA, and the locus is replaced with an exogenous sequence by supplementation with a targeting vector. The technique of gene targeting has availed scientists with the ability to control cellular genomes (Hotta \& Yamanaka, 2015). Gene targeting has however been shown to be way more challenging in human pluripotent stem cells than in mouse ES cells (Hotta \& Yamanaka, 2015) and this has been attributed to differences in developmental stages rather than species-related differences (Shi et al., 2017). Conventional gene targeting has recorded only a limited amount of success (Nichols \& Smith, 2009) hence the drive towards developing better methods of gene targeting.

Gene editing technologies have remarkably improved over the years with the recent technologies able to introduce genetic changes in a site-specific manner in iPSCs (Urbach, Schuldiner \& Benvenisty, 2004). The more recent technologies induce double-stranded DNA breaks in the region of gene modification (Urbach, Schuldiner \& Benvenisty, 2004). These programmable site-specific nucleases have evolved from 
ZFN (Hockemeyer et al., 2009; Zou et al., 2009) to TALENs (Hockemeyer et al., 2011; Sanjana et al., 2012) and the RNA guided engineered nucleases (RGEN) gotten from the bacterial clustered regularly interspaced short palindromic repeat (CRISPR)-Cas (CRISPR-associated) nine system (Perez-Pinera et al., 2013; Shalem et al., 2014). These technologies can easily correct pathology-causing genetic mutations derived from diseased patients and similarly can be used to induce specific mutations in disease-free wild-type iPSCs (Urbach, Schuldiner \& Benvenisty, 2004). Thus with this approach, genetically matched isogenic iPSCs can be generated while ensuring that true pathologies are reliably identified and not confused with genetic background variations or epiphenomena associated with line-to-line disparities (Urbach, Schuldiner \& Benvenisty, 2004). In as much as the three nucleases possess a similar mechanism of action which is the cleavage of chromosomal DNA in a location-specific manner, each of the nucleases still has its unique characteristics (Kim \& Kim, 2014). The well-documented study done by Kim \& Kim (2014) on the nucleases has been briefly summarized in Table 7. Of the three nucleases, the CRISPR-Cas9 system has however gained wide acceptance and usage in the editing of human iPSC because it is simple to design and use (Urbach, Schuldiner \& Benvenisty, 2004), thus necessitating a little more review below.

Cas9 is a large multifunctional protein having two putative nuclease domains, the HNH and RuvC-like (Doudna \& Charpentier, 2014). The HNH and the RuvC-like domains cleave the complementary 20-nucleotide sequence of the crRNA and the DNA strand opposite the complementary strand respectively (Doudna \& Charpentier, 2014). Several variants of the CRISPR-Cas9 system exists and hence the subtle diversity to their modes of action: (1) The original CRISPR-Cas9 system functions by inducing DNA double-stranded breaks which are triggered by the wild-type Cas9 nuclease directed by a single RNA (Urbach, Schuldiner \& Benvenisty, 2004). However, its major challenge is the possibility of off-target effects (Urbach, Schuldiner \& Benvenisty, 2004). (2) The nickase variant of Cas9(D10A mutant) which is generated by the mutation of either the Cas9 HNH or the RuvC-like domain (Li et al., 2011; Christian et al., 2010) is directed by paired guide RNAs. (3) Engineered nuclease variant of Cas9 with enhanced specificity (eSpCas9) (Xiao et al., 2013; Gupta et al., 2013). The nickase (D10A mutant) and the eSpCas9 variants have both been shown to substantially reduce off-target effects while still maintaining their meticulous on-target cleavage (Xiao et al., 2013; Gupta et al., 2013). (4) Catalytically dead Cas9 (dCas9) variant is generated by mutating both domains (HNH and RUvC-like) (Li et al., 2011; Christian et al., 2010). dCas9, when merged with a transcriptional suppressor or activator can be used to modify transcription of endogenous genes (CRISPRa or CRISPRi) or when fused with fluorescent protein can be used to image genomic loci (Xiao et al., 2013; Gupta et al., 2013; Cho et al., 2014). (5) A modified CRISPR-Cas9 variant has been used to efficiently introduce DNA sequences in an exact monoallelic or biallelic manner (Gaj, Gersbach \& Barbas, 2013), and (6) CRISPR-Cas9 fused with cytidine deaminase, results in a variant which induces the direct conversion of cytidine to uridine, hence circumventing the DNA double-stranded break (Segal \& Meckler, 2013). 

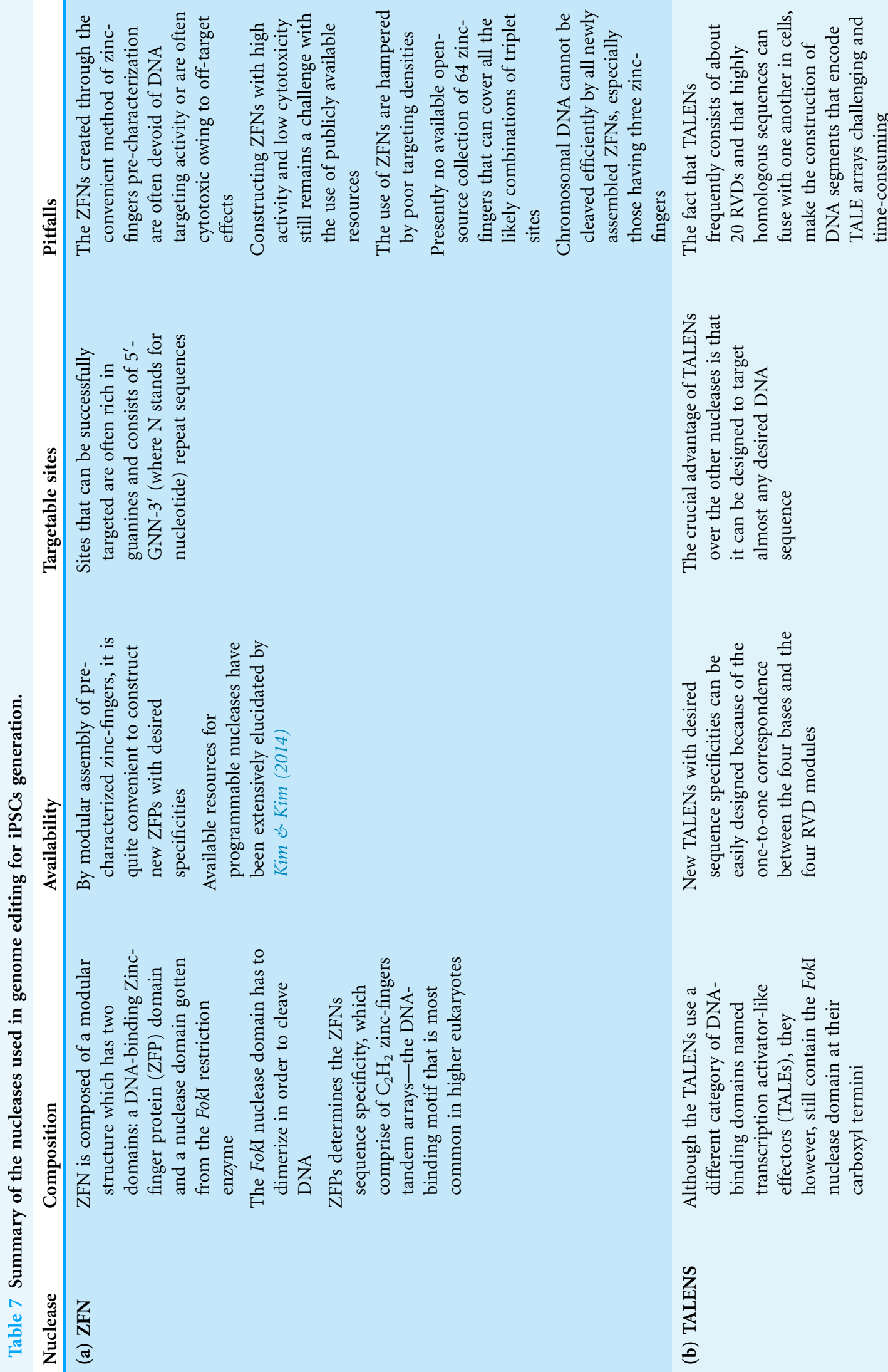


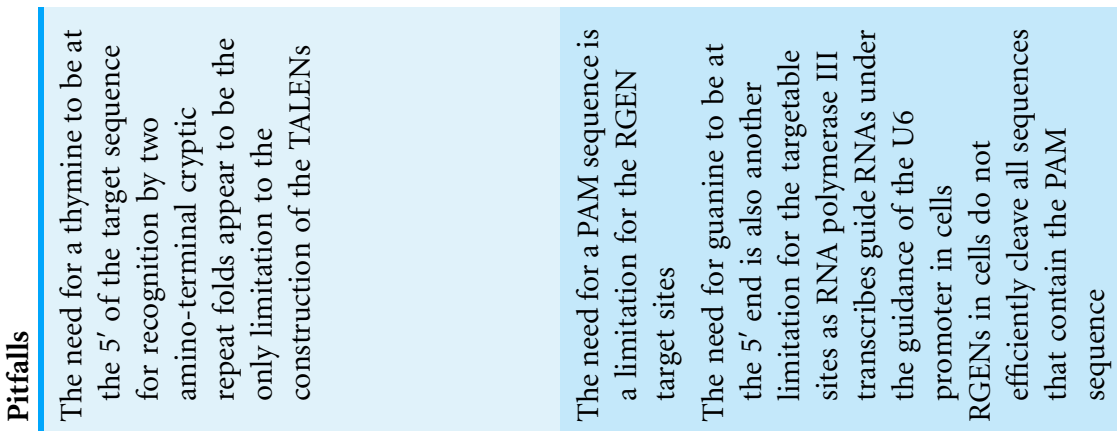

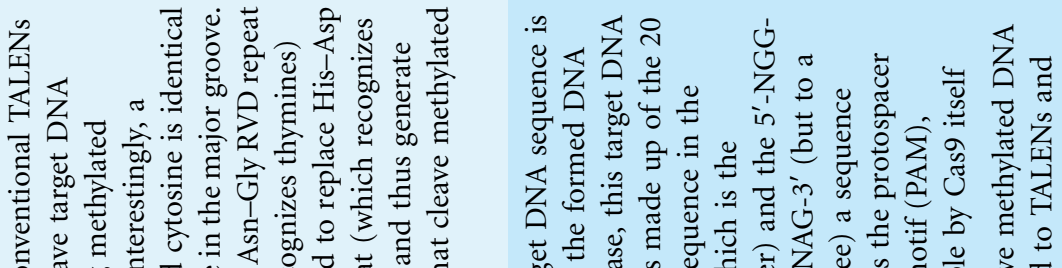

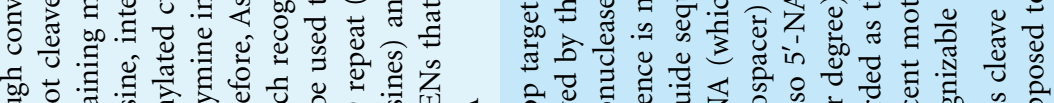

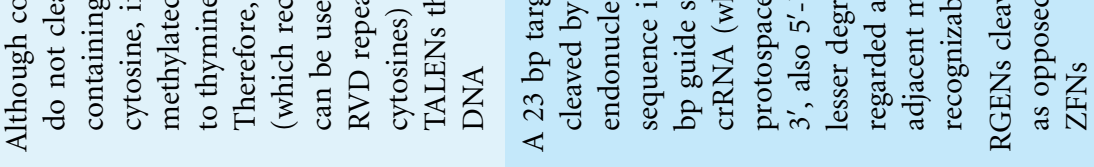

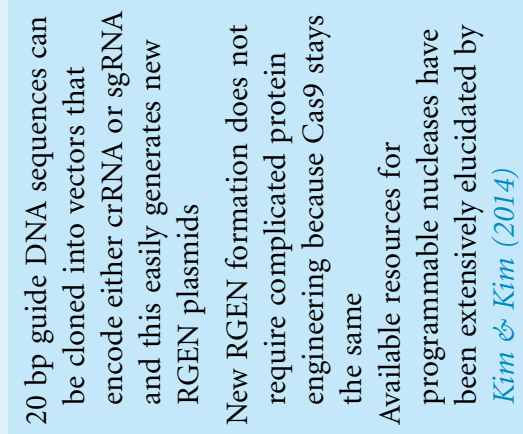

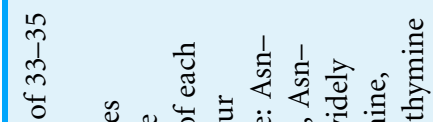

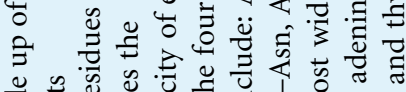




Hotta and Yamanaka have extensively reviewed how these nucleases have been used to mediate gene editing in pluripotent stem cells (Hotta \& Yamanaka, 2015). Thus it is anticipated that the combination of these two technologies (gene editing and iPSCs) might be the dawn of a new phase of gene therapy.

\section{FUTURE PERSPECTIVE}

The promise that iPSCs are viable and possibly superior substitutes for ESCs in disease modeling, drug discovery and regenerative medicine has not yet been fulfilled. Despite great success in animal models, there are still many obstacles on the road to the clinical application of iPSCs. A major limitation is the heterogeneous nature of the cell population and differentiation potential of iPSCs. Hopefully, the CRISPR-Cas 9 system can be used to address this limitation since the technology can improve the disease phenotype of differentiated cells (Hotta \& Yamanaka, 2015; Deleidi \& Yu, 2016). Another major limitation is the lack of robust lineage-specific differentiation protocols to generate large quantities of purified and matured iPSC-differentiated cells. More basic research on reprogramming technology is critical for the development of novel protocols for the generation of standardized human iPSC. A more current biotechnology, the microRNA switch (Miki et al., 2015), is expected to facilitate the maturation and purification of iPSCdifferentiated cells and to reduce clonal variation.

While we wait for these limitations to be addressed, it will be wise to bank iPSCs from patients with specific diseases. Doing so will allow us the time to guarantee the quality of these cells thus saving time and cost when they are made available for transplantation.

\section{CONCLUSION}

The discovery of iPSCs by Takahashi and Yamanaka is truly a breakthrough of the decade in stem cell science. The year 2016 marked the 10th anniversary of this landmark discovery. The last decade has witnessed remarkable advancement in our understanding of the molecular mechanisms of induced pluripotency, and we moved from the "bench to the bedside" in 2014. The more recent long-term study involving the application of human iPSC-derived dopaminergic neurons in primate Parkinson's disease (PD) models at the Center for iPS Cell Research and Application, Kyoto University, Japan, reveals that human iPSCs are clinically applicable for the treatment of patients with PD (Kikuchi et al., 2017). The iPSC-based cell therapy is still at its infant stage. The remaining barriers blocking the path to successful translation of this technology into clinical therapy have to be overcome. We believe many of these challenges are only technical and with time "this too shall pass away." The combination of the human iPSC technology with genomeediting technologies may trigger a new era of gene therapy utilizing iPSCs.

\section{ACKNOWLEDGEMENTS}

The author wish to thank Kingsley Nnawuba and David Adeiza Otohinoyi for their assistance with some of the figures and tables. 


\section{ADDITIONAL INFORMATION AND DECLARATIONS}

\section{Funding}

The authors received no funding for this work.

\section{Competing Interests}

The authors declare that they have no competing interests.

\section{Author Contributions}

- Adekunle Ebenezer Omole prepared figures and/or tables, authored or reviewed drafts of the paper.

- Adegbenro Omotuyi John Fakoya prepared figures and/or tables, authored or reviewed drafts of the paper.

\section{Data Availability}

The following information was supplied regarding data availability:

There is no raw data for this literature review.

\section{REFERENCES}

Aasen T, Raya A, Barrero MJ, Garreta E, Consiglio A, Gonzalez F, Vassena R, Bilic J, Pekarik V, Tiscornia G, Edel M, Boue S, Izpisua Belmonte JC. 2008. Efficient and rapid generation of induced pluripotent stem cells from human keratinocytes. Nature Biotechnology 26(11):1276-1284 DOI 10.1038/nbt.1503.

Anokye-Danso F, Trivedi CM, Juhr D, Gupta M, Cui Z, Tian Y, Zhang Y, Yang W, Gruber PJ, Epstein JA, Morrisey EE. 2011. Highly efficient miRNA-mediated reprogramming of mouse and human somatic cells to pluripotency. Cell Stem Cell 8(4):376-388

DOI 10.1016/j.stem.2011.03.001.

Aoi T, Yae K, Nakagawa M, Ichisaka T, Okita K, Takahashi K, Chiba T, Yamanaka S. 2008. Generation of pluripotent stem cells from adult mouse liver and stomach cells. Science 321(5889):699-702 DOI 10.1126/science.1154884.

Avilion AA, Nicolis SK, Pevny LH, Perez L, Vivian N, Lovell-Badge R. 2003. Multipotent cell lineages in early mouse development depend on $\mathrm{SOX}_{2}$ function. Genes \& Development 17(1):126-140 DOI 10.1101/gad.224503.

Ban H, Nishishita N, Fusaki N, Tabata T, Saeki K, Shikamura M, Takada N, Inoue M, Hasegawa M. 2011. Kawamata S, Nishikawa S. 2011. Efficient generation of transgene-free human induced pluripotent stem cells (iPSCs) by temperature-sensitive Sendai virus vectors. Proceedings of the National Academy of Sciences of the United States of America 108(34):14234-14239 DOI 10.1073/pnas.1103509108.

Banito A, Rashid ST, Acosta JC, Li S, Pereira CF, Geti I, Pinho S, Silva JC, Azuara V, Walsh M, Vallier L, Gil J. 2009. Senescence impairs successful reprogramming to pluripotent stem cells. Genes \& Development 23(18):2134-2139 DOI 10.1101/gad.1811609.

Bartel DP. 2004. MicroRNAs: genomics, biogenesis, mechanism and function. Cell 116:281-297.

Berdasco M, Estellar M. 2011. DNA methylation in stem cell renewal and multipotency. Stem Cell Research \& Therapy 2(5):42 DOI 10.1186/scrt83.

Bernstein BE, Mikkelsen TS, Xie X, Kamal M, Huebert DJ, Cuff J, Fry B, Meissner A, Wernig M, Plath K, Jaenisch R, Wagschal A, Feil R, Schreiber SL, Lander ES. 2006. A bivalent chromatin 
structure marks key developmental genes in embryonic stem cells. Cell 125(2):315-326 DOI 10.1016/j.cell.2006.02.041.

Bird A. 2002. DNA methylation patterns and epigenetic memory. Genes \& Development 16(1):6-21 DOI 10.1101/gad.947102.

Blelloch R, Venere M, Yen J, Ramalho-Santos M. 2007. Generation of induced pluripotent stem cells in the absence of drug selection. Cell Stem Cell 1(3):245-247

DOI 10.1016/j.stem.2007.08.008.

Bock C, Kiskinis E, Verstappen G, Gu H, Boulting G, Smith ZD, Ziller M, Croft GF, Amoroso MW, Oakley DH, Gnirke A, Eggan K, Meissner A. 2011. Reference maps of human ES and iPS cell variation enable high-throughput characterization of pluripotent cell lines. Cell 144(3):439-452 DOI 10.1016/j.cell.2010.12.032.

Boyer LA, Lee TI, Cole MF, Johnstone SE, Levine SS, Zucker JP, Guenther MJ, Kumar RM, Murray HL, Jenner RG, Gifford DK, Melton DA, Jaenisch R. 2005. Core transcriptional regulatory circuitry in human embryonic stem cells. Cell 122(6):947-956

DOI 10.1016/j.cell.2005.08.020.

Brambrink T, Foreman R, Welstead GG, Lengner CJ, Wernig M, Suh H, Jaenisch R. 2008. Sequential expression of pluripotency markers during direct reprogramming of mouse somatic cells. Cell Stem Cell 2(2):151-159 DOI 10.1016/j.stem.2008.01.004.

Bright J, Hussain S, Dang V, Wright S, Cooper B, Byun T, Ramos C, Singh A, Parry G, Stagliano N, Griswold-Prenner I. 2015. Human secreted tau increases amyloid-beta production. Neurobiology of Aging 36(2):693-709 DOI 10.1016/j.neurobiolaging.2014.09.007.

Brouwer M, Zhou H, Nadif Kasri N. 2016. Choices for induction of pluripotency: recent developments in human induced pluripotency stem cell reprogramming strategies. Stem Cell Reviews and Reports 12(1):54-72 DOI 10.1007/s12015-015-9622-8.

Buganim Y, Faddah DA, Cheng AW, Itskovich E, Markoulaki S, Ganz K, Klemm SL, van Oudenaarden A, Jaenisch R. 2012. Single-cell expression analyses during cellular reprogramming reveal an early stochastic and a late hierarchic phase. Cell 150(6):1209-1222 DOI 10.1016/j.cell.2012.08.023.

Buganim Y, Faddah DA, Jaenisch R. 2013. Mechanisms and models of somatic cell reprogramming. Nature Reviews Genetics 14(6):427-439 DOI 10.1038/nrg3473.

Carey BW, Markoulaki S, Hanna J, Saha K, Gao Q, Mitalipova M, Jaenisch R. 2009. Reprogramming of murine and human somatic cells using a single polycistronic vector. Proceedings of the National Academy of Sciences of the United States of America 106(1):157-162 DOI 10.1073/pnas.0811426106.

Cartwright P, McLean C, Sheppard A, Rivett D, Jones K, Dalton S. 2005. LIF/STAT3 controls ES cell self-renewal and pluripotency by a Myc-dependent mechanism. Development 132(5):885-896 DOI 10.1242/dev.01670.

Cell Stem Cell Editorial Team. 2016. 10 questions: clinical outlook of iPSCs. Cell Stem Cell 18(2):170-173 DOI 10.1016/j.stem.2016.01.023.

Chambers I, Colby D, Robertson M, Nichols J, Lee S, Tweedie S, Smith A. 2003. Functional expression cloning of Nanog, a pluripotency sustaining factor in embryonic stem cells. Cell 113(5):643-655 DOI 10.1016/s0092-8674(03)00392-1.

Chambers I, Silva J, Colby D, Nichols J, Nijmeijer B, Robertson M, Vrana J, Jones K, Grotewold L, Smith A. 2007. Nanog safeguards pluripotency and mediates germline development. Nature 450(7173):1230-1234 DOI 10.1038/nature06403. 
Chang CW, Lai YS, Pawlik KM, Liu K, Sun CW, Li C, Schoeb TR, Townes TM. 2009. Polycistronic lentiviral vector for "hit and run" reprogramming of adult skin fibroblasts to induced pluripotent stem cells. Stem Cells 27(5):1042-1049 DOI 10.1002/stem.39.

Chen ZY, He CY, Ehrhardt A, Kay MA. 2003. Minicircle DNA vectors devoid of bacterial DNA result in persistent and high-level transgene expression in vivo. Molecular Therapy 8(3):495-500 DOI 10.1016/s1525-0016(03)00168-0.

Chen ZY, He CY, Kay MA. 2005. Improved production and purification of minicircle DNA vector free of plasmid bacterial sequences and capable of persistent transgene expression in vivo. Human Gene Therapy 16(1):126-131 DOI 10.1089/hum.2005.16.126.

Cheng L, Hansen NF, Zhao L, Du Y, Zou C, Donovan FX, Chou BK, Zhou G, Li S, Dowey SN, Ye Z, NISC Comparative Sequencing Program, Chandrasekharappa SC, Yang H, Mullikin JC, Liu PP. 2012. Low incidence of DNA sequence variation in human induced pluripotent stem cells generated by nonintegrating plasmid expression. Cell Stem Cell 10(3):337-344 DOI 10.1016/j.stem.2012.01.005.

Chew JL, Loh YH, Zhang W, Chen X, Tam WL, Yeap LS, Li P, Ang YS, Lim B, Robson P, Ng HH. 2005. Reciprocal transcriptional regulation of Pouff1 and Sox2 via the Oct $4 /$ Sox 2 complex in embryonic stem cells. Molecular and Cellular Biology 25(14):6031-6046 DOI 10.1128/mcb.25.14.6031-6046.2005.

Chin MH, Mason MJ, Xie W, Volinia S, Singer M, Peterson C, Ambartsumyan G, Aimiuwu O, Richter L, Zhang J, Khvorostov I, Ott V, Grunstein M, Lavon N, Benvenisty N, Croce CM, Clark AT, Baxter T, Pyle AD, Teitell MA, Pelegrini M, Plath K, Lowry WE. 2009. Induced pluripotent stem cells and embryonic stem cells are distinguished by gene expression signatures. Cell Stem Cell 5(1):111-123 DOI 10.1016/j.stem.2009.06.008.

Cho SW, Kim S, Kim Y, Kweon J, Kim HS, Bae S, Kim J. 2014. Analysis of off-target effects of CRISPR/Cas-derived RNA-guided endonucleases and nickases. Genome Research 24(1):132-141 DOI 10.1101/gr.162339.113.

Choi MS, Kim Y, Shim JS, Park JT, Wang RH, Leach SD, Liu JO, Deng C, Ye Z, Jang YY. 2013. Efficient drug screening and gene correction for treating liver disease using patient-specific stem cells. Hepatology 57(6):2458-2468 DOI 10.1002/hep.26237.

Christian M, Cermak T, Doyle EL, Schmidt C, Zhang F, Hummel A, Bogdanove AJ, Voytas DF. 2010. Targeting DNA double-strand breaks with TAL effector nucleases. Genetics 186(2):757-761 DOI 10.1534/genetics.110.120717.

Chun YS, Byun K, Lee B. 2011. Induced pluripotent stem cells and personalized medicine: current progress and future perspectives. Anatomy \& Cell Biology 44(4):245-255 DOI 10.5115/acb.2011.44.4.245.

Chung TL, Brena RM, Kolle G, Grimmond SM, Berman BP, Laird PW, Pera MF, Wolvetang EJ. 2010. Vitamin C promotes widespread yet specific DNA demethylation of the epigenome in human embryonic stem cells. Stem Cells 28(10):1848-1855 DOI 10.1002/stem.493.

Cong L, Ran FA, Cox D, Lin S, Barretto R, Habib N, Hsu PD, Wu X, Jiang W, Marraffini LA, Zhang F. 2013. Multiplex genomic engineering using CRISPR-Cas systems. Science 339(6121):819-823 DOI 10.1126/science.1231143.

Dang CV, O'Donnell KA, Zeller KI, Nguyen T, Osthus RC, Li F. 2006. The c-Myc target gene network. Seminars in Cancer Biology 16(4):253-264 DOI 10.1016/j.semcancer.2006.07.014.

Dang DT, Pevsner J, Yang VW. 2000. The biology of the mammalian Kruppel-like family of transcription factors. International Journal of Biochemistry \& Cell Biology 32(11-12):1103-1121 DOI 10.1016/s1357-2725(00)00059-5. 
Davis RP, Nemes C, Varga E, Freund C, Kosmidis G, Gkatzis K, de Jong D, Szuhai K, Dinnyes A, Mummery CL. 2013. Generation of induced pluripotent stem cells from human foetal fibroblasts using the Sleeping Beauty transposon gene delivery system. Differentiation 86(1-2):30-37 DOI 10.1016/j.diff.2013.06.002.

Deleidi M, Yu C. 2016. Genome editing in pluripotent stem cells: research and therapeutic applications. Biochemical and Biophysical Research Communications 473(3):665-674 DOI 10.1016/j.bbrc.2016.02.113.

Doege CA, Inoue K, Yamashita T, Rhee DB, Travis S, Fujita R, Guarnieri P, Bhagat G, Vanti WB, Shih A, Levine RL, Nik S, Chen EI, Abeliovich A. 2012. Early-stage epigenetic modification during somatic cell reprogramming by Parp1 and Tet2. Nature 488(7413):625-655 DOI 10.1038/nature11333.

Doudna JA, Charpentier E. 2014. Genome editing. The new frontier of genome engineering with CRISPR-Cas9. Science 346(6213):1258096.

Ebert AD, Yu J, Rose FF Jr, Mattis VB, Lorson CL, Thomson JA, Svendsen CN. 2009. Induced pluripotent stem cells from a spinal muscular atrophy patient. Nature 457(7227):277-280 DOI 10.1038/nature07677.

Edel MJ, Menchon C, Menendez S, Consiglio A, Raya A, Izpisua Belmonte JC. 2010. Rem2 GTPase maintains survival of human embryonic stem cells as well as enhancing reprogramming by regulating p53 and cyclin D1. Genes \& Development 24(6):561-573 DOI 10.1101/gad.1876710.

Eminli S, Foudi A, Stadtfeld M, Maherali N, Ahfeldt T, Mostoslavsky G, Hock H, Hochedlinger K. 2009. Differentiation stage determines potential of hematopoietic cells for reprogramming into induced pluripotent stem cells. Nature Genetics 41(9):968-976 DOI 10.1038/ng.428.

Eminli S, Utikal J, Arnold K, Jaenisch R, Hochedlinger K. 2008. Reprogramming of neural progenitor cells into induced pluripotent stem cells in the absence of exogenous Sox2 expression. Stem Cells 26(10):2467-2474 DOI 10.1634/stemcells.2008-0317.

Esteban MA, Wang T, Qin B, Yang J, Qin D, Cai J, Li W, Weng Z, Chen J, Ni S, Chen K, Li Y, Liu X, Xu J, Zhang S, Li F, He W, Labuda K, Song Y, Peterbauer A, Wolbank S, Redl H, Zhong M, Cai D, Zeng L, Pei D. 2010. Vitamin C enhances the generation of mouse and human induced pluripotent stem cells. Cell Stem Cell 6(1):71-79 DOI 10.1016/j.stem.2009.12.001.

Evans MJ, Kaufman MH. 1981. Establishment in culture of pluripotential cells from mouse embryos. Nature 292(5819):154-156 DOI 10.1038/292154a0.

Feldman N, Gerson A, Fang J, Li E, Zhang Y, Shinkai Y, Cedar H, Bergman Y. 2006. G9a-mediated irreversible epigenetic inactivation of Oct3/4 during early embryogenesis. Nature Cell Biology 8(2):188-194 DOI 10.1038/ncb1353.

Feng B, Jiang J, Kraus P, Ng JH, Heng JC, Chan YS, Yaw LP, Zhang W, Loh YH, Han J, Vega VB, Cacheux-Rataboul V, Lim B, Lufkin T, Ng HH. 2009. Reprogramming of fibroblasts into induced pluripotent stem cells with orphan nuclear receptor Esrrb. Nature Cell Biology 11(2):197-203 DOI 10.1038/ncb1827.

Feschotte C. 2006. The piggyBac transposon holds promise for human gene therapy. Proceedings of the National Academy of Sciences of the United States of America 103(41):14981-14982 DOI 10.1073/pnas.0607282103.

Fusaki N, Ban H, Nishiyama A, Saeki K, Hasegawa M. 2009. Efficient induction of transgene-free human pluripotent stem cells using a vector based on Sendai virus, an RNA virus that does not integrate into the host genome. Proceedings of the Japan Academy. Series B, Physical and Biological Sciences 85(8):348-362 DOI 10.2183/pjab.85.348. 
Fussner E, Djuric U, Strauss M, Hotta A, Perez-Iratxeta C, Lanner F, Dilworth FJ, Ellis J, BazettJones DP. 2011. Constitutive heterochromatin reorganization during somatic cell reprogramming. EMBO Journal 30(9):1178-1189 DOI 10.1038/emboj.2011.96.

Gaj T, Gersbach CA, Barbas CF 3rd. 2013. ZFN, TALEN, and CRISPR/Cas-based methods for genome engineering. Trends in Biotechnology 31(7):397-405 DOI 10.1016/j.tibtech.2013.04.004.

Gao Y, Chen J, Li K, Wu T, Huang B, Liu W, Kou X, Zhang Y, Huang H, Jiang Y, Yao C, Liu X, Lu Z, Xu Z, Kang L, Chen J, Wang H, Cai T, Gao S. 2013. Replacement of Oct4 by Tet1 during iPSC induction reveals an important role of DNA methylation and hydroxymethylation in reprogramming. Cell Stem Cell 12(4):453-469 DOI 10.1016/j.stem.2013.02.005.

Ghaleb AM, Nandan MO, Chanchevalap S, Dalton WB, Hisamuddin IM, Yang VW. 2005. Kruppel-like factors 4 and 5: the yin and yang regulators of cellular proliferation. Cell Research 15(2):92-96 DOI 10.1038/sj.cr.7290271.

Gladych M, Andrzejewska A, Oleksiewicz U, Estecio MR. 2015. Epigenetic mechanisms of induced pluripotency. Contemporary Oncology (Pozn) 19:A30-A38.

Gonzalez F, Barragan Monasterio M, Tiscornia G, Montserrat Pulido N, Vassena R, Batlle Morera L, Rodriguez Piza I, Izpisua Belmonte JC. 2009. Generation of mouse-induced pluripotent stem cells by transient expression of a single nonviral polycistronic vector. Proceedings of the National Academy of Sciences of the United States of America 106(22):8918-8922 DOI 10.1073/pnas.0901471106.

Gonzalez F, Boue S, Izpisua Belmonte JC. 2011. Methods for making induced pluripotent stem cells: reprogramming a la carte. Nature Reviews Genetics 12(4):231-242 DOI 10.1038/nrg2937.

Gonzalez F, Huangfu D. 2016. Mechanisms underlying the formation of induced pluripotent stem cells. Wiley Interdisciplinary Reviews: Developmental Biology 5(1):39-65 DOI 10.1002/wdev.206.

Goodell MA, Nguyen H, Shroyer N. 2015. Somatic stem cell heterogeneity: diversity in the blood, skin and intestinal stem cell compartments. Nature Reviews Molecular Cell Biology 16(5):299-309 DOI 10.1038/nrm3980.

Grabundzija I, Irgang M, Mates L, Belay E, Matrai J, Golgo-Doring A, Kawakami K, Chen W, Ruiz P, Chuah MK, VandenDriessche T, Izsvak Z, Ivics Z. 2010. Comparative analysis of transposable element vector systems in human cells. Molecular Therapy 18(6):1200-1209 DOI 10.1038/mt.2010.47.

Grabundzija I, Wang J, Sebe A, Erdei Z, Kajdi R, Devaraj A, Steinemann D, Szuhai K, Stein U, Cantz T, Schambach A, Baum C, Izsvak Z, Sarkadi B, Ivics Z. 2013. Sleeping Beauty transposon-based system for cellular reprogramming and targeted gene insertion in induced pluripotent stem cells. Nuclei Acids Research 41(3):1829-1847 DOI 10.1093/nar/gks1305.

Guenther MG, Frampton GM, Soldner F, Hockemeyer D, Mitalipova M, Jaenisch R, Young RA. 2010. Chromatin structure and gene expression programs of human embryonic and induced pluripotent stem cells. Cell Stem Cell 7(2):249-257 DOI 10.1016/j.stem.2010.06.015.

Guha P, Morgan JW, Mostoslavsky G, Rodrigues NP, Boyd AS. 2013. Lack of immune response to differentiated cells derived from syngeneic induced pluripotent stem cells. Cell Stem Cell 12(4):407-412 DOI 10.1016/j.stem.2013.01.006.

Guo G, Yang J, Nichols J, Hall JS, Eyres I, Mansfield W, Smith A. 2009. Klf4 reverts developmentally programmed restriction of ground state pluripotency. Development 136(7):1063-1069 DOI 10.1242/dev.030957.

Gupta A, Hall VL, Kok FO, Shin M, McNulty JC, Lawson ND, Wolfe SA. 2013. Targeted chromosomal deletions and inversions in zebrafish. Genome Research 23(6):1008-1017 DOI 10.1101/gr.154070.112. 
Gurdon JB. 1962. The developmental capacity of nuclei taken from intestinal epithelium cells of feeding tadpoles. Journal of Embryology and Experimental Morphology 10:622-640.

Gurdon JB, Yamanaka S. 2012. The 2012 Nobel Prize in Physiology or Medicine-Press Release. Nobel Media AB. 8 October, 2012. Available at http://www.nobelprize.org/nobel_prizes/medicine/ laureates/2012/press.html (accessed 31 March 2017).

Hanna J, Markoulaki S, Schorderet P, Carey BW, Beard C, Wernig M, Creyghton MP, Steine EJ, Cassady JP, Foreman R, Lengner CJ, Dausman JA, Jaenisch R. 2008. Direct reprogramming of terminally differentiated mature B lymphocytes to pluripotency. Cell 133(2):250-264 DOI 10.1016/j.cell.2008.03.028.

Hanna J, Wernig M, Markoulaki S, Sun CW, Meissner A, Cassady JP, Beard C, Brambrink T, Wu LC, Townes TM, Jaenisch R. 2007. Treatment of sickle cell anemia mouse model with iPS cells generated from autologous skin. Science 318(5858):1920-1923

DOI 10.1126/science.1152092.

Hansson J, Rafiee MR, Reiland S, Polo JM, Gehring J, Okawa S, Huber W, Hochedlinger K, Krijgsveld J. 2012. Highly coordinated proteome dynamics during reprogramming of somatic cells to pluripotency. Cell Reports 2(6):1579-1592 DOI 10.1016/j.celrep.2012.10.014.

Hochedlinger K, Yamada Y, Beard C, Jaenisch R. 2005. Ectopic expression of Oct-4 blocks progenitor-cell differentiation and causes dysplasia in epithelial tissues. Cell 121(3):465-477 DOI 10.1016/j.cell.2005.02.018.

Hockemeyer D, Soldner F, Beard C, Gao Q, Mitalipova M, DeKelver RC, Katibah GE, Amora R, Boydston EA, Zeitler B, Meng X, Miller JC, Zhang L, Rebar EJ, Gregory PD, Urnov FD, Jaenisch R. 2009. Efficient targeting of expressed and silent genes in human ESCs and iPSCs using zinc-finger nucleases. Nature Biotechnology 27(9):851-857 DOI 10.1038/nbt.1562.

Hockemeyer D, Soldner F, Cook EG, Gao Q, Mitalipova M, Jaenisch R. 2008. A drug-inducible system for direct reprogramming of human somatic cells to pluripotency. Cell Stem Cell 3(3):346-353 DOI 10.1016/j.stem.2008.08.014.

Hockemeyer D, Wang H, Kiani S, Lai CS, Gao Q, Cassady JP, Cost GJ, Zhang L, Santiago Y, Miller JC, Zeitler B, Cherone JM, Meng X, Hinkley SJ, Rebar EJ, Gregory PD, Urnov FD, Jaenisch R. 2011. Genetic engineering of human pluripotent cells using TALE nucleases. Nature Biotechnology 29(8):731-734 DOI 10.1038/nbt.1927.

Hong H, Takahashi K, Ichisaka T, Aoi T, Kanagawa O, Nakagawa M, Okita K, Yamanaka S. 2009. Suppression of induced pluripotent stem cell generation by the p53-p21 pathway. Nature 460(7259):1132-1135 DOI 10.1038/nature08235.

Hotta A, Yamanaka S. 2015. From genomics to gene therapy: induced pluripotent stem cells meet genome editing. Annual Review of Genetics 49(1):47-70 DOI 10.1146/annurev-genet-112414-054926.

Huangfu D, Maehr R, Guo W, Eijkelenboom A, Snitow M, Chen AE, Melton DA. 2008a. Induction of pluripotent stem cells by defined factors is greatly improved by small-molecule compounds. Nature Biotechnology 26(7):795-797 DOI 10.1038/nbt1418.

Huangfu D, Osafune K, Maehr R, Guo W, Eijkelenboom A, Chen S, Muhlestein W, Melton DA. 2008b. Induction of pluripotent stem cells from primary human fibroblasts with only Oct 4 and Sox2. Nature Biotechnology 26(11):1269-1275 DOI 10.1038/nbt.1502.

Inoue M, Tokusumi Y, Ban H, Kanaya T, Tokusumi T, Nagai Y, lida A, Hasegawa M. 2003. Nontransmissible virus-like particle formation by F-deficient Sendai virus is temperature sensitive and reduced by mutations in M and HN proteins. Journal of Virology 77(5):3238-3246 DOI 10.1128/jvi.77.5.3238-3246.2003. 
Itzhaki I, Maizels L, Huber I, Zwi-Dantsis L, Caspi O, Winterstern A, Feldman O, Gepstein A, Arbel G, Hammerman H, Boulos M, Gepstein L. 2011. Modelling the long QT syndrome with induced pluripotent stem cells. Nature 471(7337):225-229 DOI 10.1038/nature09747.

Jaenisch R, Young R. 2008. Stem cells, the molecular circuitry of pluripotency and nuclear reprogramming. Cell 132(4):567-582 DOI 10.1016/j.cell.2008.01.015.

Jahner D, Stuhlmann H, Stewart CL, Harbers K, Lohler J, Simon I, Jaenisch R. 1982. De novo methylation an expression of retroviral genomes during mouse embryogenesis. Nature 298(5875):623-628 DOI 10.1038/298623a0.

Jia F, Wilson KD, Sun N, Gupta DM, Huang M, Li Z, Panetta NJ, Chen ZY, Robbins RC, Kay MA, Longaker MT, Wu JC. 2010. A nonviral minicircle vector for deriving human iPS cells. Nature Methods 7(3):197-199 DOI 10.1038/nmeth.1426.

Jinek M, Chylinski K, Fonfara I, Hauer M, Doudna JA, Charpentier E. 2012. A programmable dual-RNA-guided DNA endonuclease in adaptive bacterial immunity. Science 337(6096):816-821 DOI 10.1126/science.1225829.

Judson RL, Babiarz JE, Venere M, Blelloch R. 2009. Embryonic stem cell-specific microRNAs promote induced pluripotency. Nature Biotechnology 27(5):459-461 DOI 10.1038/nbt.1535.

Kaji K, Norrby K, Paca A, Mileikovsky M, Mohseni P, Woltjen K. 2009. Virus-free induction of pluripotency and subsequent excision of reprogramming factors. Nature 458(7239):771-775 DOI 10.1038/nature07864.

Kawagoe S, Higuchi T, Otaka M, Shimada Y, Kobayashi H, Ida H, Ohashi T, Okano HJ, Nakanishi M, Eto Y. 2013. Morphological features of iPS cells generated from Fabry disease skin fibroblasts using Sendai virus vector ( $\mathrm{SeV} \mathrm{dp}$ ). Molecular Genetics and Metabolism 109(4):386-389 DOI 10.1016/j.ymgme.2013.06.003.

Kawamura T, Suzuki J, Wang YV, Menendez S, Morera LB, Raya A, Wahl GM, Izpisua Belmonte JC. 2009. Linking the p53 tumour suppressor pathway to somatic cell reprogramming. Nature 460(7259):1140-1144 DOI 10.1038/nature08311.

Kikuchi T, Morizane A, Doi D, Magotani H, Onoe H, Hayashi T, Mizuma H, Takara S, Takahashi R, Inoue H, Morita S, Yamamoto M, Okita K, Nakagawa M, Parmar M, Takahashi J. 2017. Human iPS cell-derived dopaminergic neurons function in a primate Parkinson's disease model. Nature 548(7669):592-596 DOI 10.1038/nature23664.

Kim H, Kim J. 2014. A guide to genome engineering with programmable nucleases. Nature Reviews Genetics 15(5):321-334 DOI 10.1038/nrg3686.

Kim K, Doi A, Wen B, Ng K, Zhao R, Cahan P, Kim J, Aryee MJ, Ji H, Ehrlich LIR, Yabuuchi A, Takeuchi A, Cunniff KC, Hongguang H, Mckinney-Freeman S, Naveiras O, Yoon TJ, Irizarry RA, Jung N, Seita J, Hanna J, Murakami P, Jaenisch R, Weissleder R, Orkin SH, Weissman IL, Feinberg AP, Daley GQ. 2010a. Epigenetic memory in induced pluripotent stem cells. Nature 467(7313):285-290 DOI 10.1038/nature09342.

Kim K, Zhao R, Doi A, Ng K, Unternaehrer J, Cahan P, Hongguang H, Loh YH, Aryee MJ, Lensch MW, Li H, Collins JJ, Feinberg AP, Daley GQ. 2010b. Donor cell type can influence the epigenome and differential potential of human induced pluripotent stem cells. Nature Biotechnology 29(12):1117-1119 DOI 10.1038/nbt.2052.

Kim D, Kim CH, Moon JI, Chung YG, Chang MY, Han BS, Ko S, Yang E, Cha KY, Lanza R, Kim KS. 2009. Generation of human induced pluripotent stem cells by direct delivery of reprogramming proteins. Cell Stem Cell 4(6):472-476 DOI 10.1016/j.stem.2009.05.005.

Kim JB, Zaehres H, Wu G, Gentile L, Ko K, Sebastiano V, Arauzo-Bravo MJ, Ruau D, Han DW, Zenke M, Scholer HR. 2008. Pluripotent stem cells induced from adult neural stem cells by reprogramming with two factors. Nature 454(7204):646-650 DOI 10.1038/nature07061. 
Kimbrel EA, Lanza R. 2015. Current status of pluripotent stem cells: moving the first therapies to the clinic. Nature Reviews Drug Discovery 14(10):681-692 DOI 10.1038/nrd4738.

Knoepfler PS, Zhang XY, Cheng PF. 2006. Myc influences global chromatin structure. EMBO Journal 25(12):2723-2734 DOI 10.1038/sj.emboj.7601152.

Kuroda T, Tada M, Kubota H, Kimura H, Hatano SY, Suemori H, Nakatsuji N, Tada T. 2005. Octamer and Sox elements are required for transcriptional cis regulation of Nanog gene expression. Molecular and Cellular Biology 25(6):2475-2485 DOI 10.1128/mcb.25.6.2475-2485.2005.

Kuttler F, Mai S. 2006. c-Myc, genomic instability and disease. Genome Dynamics 1:171-190 DOI 10.1159/000092507.

Lebofsky R, Walter JC. 2007. New Myc-anisms for DNA replication and tumorigenesis? Cancer cell 12(2):102-103 DOI 10.1016/j.ccr.2007.07.013.

Lee G, Papapetrou EP, Kim H, Chambers SM, Tomishima MJ, Fasano CA, Ganat YM, Menon J, Shimizu F, Viale A, Tabar V, Sadelain M, Studer L. 2009. Modelling pathogenesis and treatment of familial dysautonomia using patient-specific iPSCs. Nature 461(7262):402-406 DOI 10.1038/nature08320.

Li E, Bestor TH, Jaenisch R. 1992. Targeted mutation of the DNA methyltransferase gene results in embryonic lethality. Cell 69(6):915-926 DOI 10.1016/0092-8674(92)90611-f.

Li H, Collado M, Villasante A, Strati K, Ortega S, Canamero M, Blasco MA, Serrano M. 2009a. The Ink4/Arf locus is a barrier for iPS cell reprogramming. Nature 460(7259):1136-1139 DOI 10.1038/nature08290.

Li W, Zhou H, Abujarour R, Zhu S, Young Joo J, Lin T, Hao E, Scholer HR, Hayek A, Ding S. 2009b. Generation of human-induced pluripotent stem cells in the absence of exogenous Sox2. Stem Cells 27:2992-3000 DOI 10.1002/stem.240.

Li T, Huang S, Jiang WZ, Wright D, Spalding MH, Weeks DP, Yang B. 2011. TAL nucleases (TALNs): hybrid proteins composed of TAL effectors and Fok1 DNA-cleavage domain. Nucleic Acids Research 39(1):359-372 DOI 10.1093/nar/gkq704.

Li Y, McClintick J, Zhong L, Edenberg HJ, Yoder MC, Chan RJ. 2005. Murine embryonic stem cell differentiation is promoted by SOCS-3 and inhibited by the zinc finger transcription factor Klf4. Blood 105(2):635-637 DOI 10.1182/blood-2004-07-2681.

Li HO, Zhu YF, Asakawa M, Kuma H, Hirata T, Ueda Y, Lee YS, Fukumura M, lida A, Kato A, Nagai Y, Hasegawa M. 2000. A cytoplasmic RNA vector derived from nontransmissible Sendai virus with efficient gene transfer and expression. Journal of Virology 74(14):6564-6569 DOI 10.1128/jvi.74.14.6564-6569.2000.

Lin SL, Chang DC, Lin CH, Ying SY, Leu D, Wu DT. 2011. Regulation of somatic cell reprogramming through inducible mir-302 expression. Nucleic Acids Research 39(3):1054-1065 DOI 10.1093/nar/gkq850.

Lin SL, Chang DC, Ying SY, Leu D, Wu DT. 2010. MicroRNA miR-302 inhibits the tumorigenicity of human pluripotent stem cells by coordinate suppression of the CDK2 and CDK4/6 cell cycle pathways. Cancer Research 70(22):9473-9482 DOI 10.1158/0008-5472.can-10-2746.

Lister R, Pelizzola M, Kida YS, Hawkins RD, Nery JR, Hon G, Antosiewicz-Bourget J, O'Malley R, Castanon R, Klugman S, Downes M, Yu R, Stewart R, Ren B, Thomson JA, Evans RM, Ecker JR. 2011. Hot-spots of aberrant epigenomic reprogramming in human induced pluripotent stem cells. Nature 471(7336):68-73 DOI 10.1038/nature09798.

Loewer S, Cabili MN, Guttman M, Loh YH, Thomas K, Park IH, Garber M, Curran M, Onder T, Agarwal S, Manos PD, Datta S, Lander ES, Schlaeger TM, Daley GQ, Rinn JL. 2010. Large 
intergenic non-coding RNA-RoR modulates reprogramming of human induced pluripotent stem cells. Nature Genetics 42(12):1113-1117 DOI 10.1038/ng.710.

Loh YH, Wu Q, Chew JL, Vega VB, Zhang W, Chen X, Bourque G, George J, Leong B, Liu J, Wong KY, Sung KW, Lee CW, Zhao XD, Chiu KP, Lipovich L, Kuznetsov VA, Robson P, Stanton LW, Wei CL, Ruan Y, Lim B, Ng HH. 2006. The Oct4 and Nanog transcription network regulates pluripotency in mouse embryonic stem cells. Nature Genetics 38(4):431-440 DOI 10.1038/ng1760.

Lowry WE, Richter L, Yachechko R, Pyle AD, Tchieu J, Sridharan R, Clark AT, Plath K. 2008. Generation of human induced pluripotent stem cells from dermal fibroblasts. Proceedings of the National Academy of Sciences of the United States of America 105(8):2883-2888 DOI 10.1073/pnas.0711983105.

Macarthur CC, Fontes A, Ravinder N, Kuninger D, Kaur J, Bailey M, Taliana A, Vemuri MC, Lieu PT. 2012. Generation of human pluripotent stem cells by a non-integrating RNA Sendai virus vector in feeder-free or xeno-free conditions. Stem Cells International 2012:564612 DOI 10.1155/2012/564612.

Maherali N, Ahfeldt T, Rigamonti A, Utikal J, Cowan C, Hochedlinger K. 2008. A high-efficiency system for the generation and study of human induced pluripotent stem cells. Cell Stem Cell 3(3):340-345 DOI 10.1016/j.stem.2008.08.003.

Maherali N, Sridharan R, Xie W, Utikal J, Eminli S, Arnold K, Stadtfeld M, Yachechko R, Tchieu J, Jaenisch R, Plath K, Hochedlinger K. 2007. Directly reprogrammed fibroblasts show global epigenetic remodeling and widespread tissue contribution. Cell Stem Cell 1(1):55-70 DOI 10.1016/j.stem.2007.05.014.

Mali P, Ye Z, Hommond HH, Yu X, Lin J, Chen G, Zou J, Cheng L. 2008. Improved efficiency and pace of generating induced pluripotent stem cells from human adult and fetal fibroblasts. Stem Cells 26(8):1998-2005 DOI 10.1634/stemcells.2008-0346.

Marchetto MC, Yeo GW, Kainohana O, Marsala M, Gage FH, Muotri AR. 2009. Transcriptional signature and memory retention of human-induced pluripotent stem cells. PLOS ONE 4(9): e7076 DOI 10.1371/journal.pone.0007076.

Marion RM, Strati K, Li H, Murga M, Blanco R, Ortega S, Fernandez-Capetillo O, Serrano M, Blasco MA. 2009. A p53-mediated DNA damage response limits reprogramming to ensure iPS cell genomic integrity. Nature 460(7259):1149-1153 DOI 10.1038/nature08287.

Martin GR. 1981. Isolation of a pluripotent cell line from early mouse embryos cultured in medium conditioned by teratocarcinoma stem cells. Proceedings of the National Academy of Sciences of the United States of America 78(12):7634-7638 DOI 10.1073/pnas.78.12.7634.

Martinez Y, Bena F, Gimelli S, Tirefort D, Dubois-Dauphin M, Krause KH, Preynat-Seauve O. 2012. Cellular diversity within embryonic stem cells: pluripotent clonal sublines show distinct differentiation potential. Journal of Cellular and Molecular Medicine 16(3):456-467

DOI 10.1111/j.1582-4934.2011.01334.x.

Masui S, Nakatake Y, Toyooka Y, Shimosato D, Yagi R, Takahashi K, Okochi H, Okuda A, Matoba R, Sharov AA, Ko MS, Niwa H. 2007. Pluripotency governed by Sox2 via regulation of Oct3/4 expression in mouse embryonic stem cells. Nature Cell Biology 9(6):625-635 DOI 10.1038/ncb1589.

McNeish J, Gardner JP, Wainger BJ, Woolf CJ, Eggan K. 2015. From dish to bedside: lessons learned while translating findings from a stem cell model of disease to a clinical trial. Cell Stem Cell 17(1):8-10 DOI 10.1016/j.stem.2015.06.013.

Melton C, Judson RL, Blelloch R. 2010. Opposing microRNA families regulate self-renewal in mouse embryonic stem cells. Nature 463(7281):621-626 DOI 10.1038/nature08725. 
Miki K, Endo K, Takahashi S, Funakoshi S, Takei I, Katayama S, Toyoda T, Kotaka M, Takaki T, Umeda M, Okubo C, Nishikawa M, Oishi A, Narita M, Miyashita I, Asano K, Hayashi K, Osafune K, Yamanaka S, Saito H, Yoshida Y. 2015. Efficient detection and purification of cell populations using synthetic microRNA switches. Cell Stem Cell 16(6):699-711 DOI 10.1016/j.stem.2015.04.005.

Mitsui K, Tokuzawa Y, Itoh H, Segawa K, Murakami M, Takahashi K, Maruyama M, Maeda M, Yamanaka S. 2003. The homeoprotein Nanog is required for maintenance of pluripotency in mouse epiblast and ES cells. Cell 113(5):631-642 DOI 10.1016/s0092-8674(03)00393-3.

Miyoshi N, Ishii H, Nagano H, Haraguchi N, Dewi DL, Kano Y, Nishikawa S, Tanemura M, Mimori K, Tanaka F, Saito T, Nishimura J, Takemasa I, Mizushima T, Ikeda M, Yamamoto H, Sekimoto M, Doki Y, Mori M. 2011. Reprogramming of mouse and human stem cells to pluripotency using mature microRNAs. Cell Stem Cell 8(6):633-638 DOI 10.1016/j.stem.2011.05.001.

Montserrat N, Garreta E, Gonzalez F, Gutierrez J, Eguizabal C, Ramos V, Borros S, Izpisua Belmonte JC. 2011. Simple generation of human induced pluripotent stem cells using poly-beta-amino esters as the non-viral gene delivery system. Journal of Biological Chemistry 286(14):12417-12428 DOI 10.1074/jbc.m110.168013.

Mullard A. 2015. Stem-cell discovery platforms yield first clinical candidates. Nature Reviews Drug Discovery 14(9):589-591 DOI 10.1038/nrd4708.

Nakagawa M, Koyanagi M, Tanabe K, Takahashi K, Ichisaka T, Aoi T, Okita K, Mochiduki Y, Takizawa N, Yamanaka S. 2008. Generation of induced pluripotent stem cells without Myc from mouse and human fibroblasts. Nature Biotechnology 26(1):101-106 DOI 10.1038/nbt1374.

Nakanishi M, Otsu M. 2012. Development of Sendai virus vectors and their potential applications in gene therapy and regenerative medicine. Current Gene Therapy 12(5):410-416 DOI 10.2174/156652312802762518.

Nakatake Y, Fukui N, Iwamatsu Y, Masui S, Takahashi K, Yagi R, Yagi K, Miyazaki J, Matoba R, Ko MS, Niwa H. 2006. Klf4 cooperates with with Oct3/4 and Sox2 to activate the Lefty1 core promoter in embryonic stem cells. Molecular and Cellular Biology 26(20):7772-7782 DOI 10.1128/mcb.00468-06.

Narsinh KH, Jia F, Robbins RC, Kay MA, Longaker MT, Wu JC. 2011. Generation of adult human induced pluripotent stem cells using nonviral minicircle DNA vectors. Nature Protocols 6(1):78-88 DOI 10.1038/nprot.2010.173.

Naryshkin NA, Weetall M, Dakka A, Narasimhan J, Zhao X, Feng Z, Ling KK, Karp GM, Qi H, Woll MG, Chen G, Zhang N, Gabbeta V, Vazirani P, Bhattacharyya A, Furia B, Risher N, Sheedy J, Kong R, Ma J, Turpoff A, Lee CS, Zhang X, Moon YC, Trifillis P, Welch EM, Colacino JM, Babiak J, Almstead NG, Peltz SW, Eng LA, Chen KS, Mull JL, Lynes MS, Rubin LL, Fontoura P, Santarelli L, Haehnke D, McCarthy KD, Schmucki R, Ebeling M, Sivaramakrishnan M, Ko CP, Paushkin SV, Ratni H, Gerlach I, Ghosh A, Metzger F. 2014. SMN2 splicing modifiers improve motor function and longevity in mice with spinal muscular atrophy. Science 345:688-693.

Newman JC, Bailey AD, Fan HY, Pavelitz T, Weiner AM. 2008. An abundant evolutionarily conserved CSB-PiggyBac fusion protein expressed in Cockayne syndrome. PLOS Genetics 4(3):e1000031 DOI 10.1371/journal.pgen.1000031.

Newman AM, Cooper JB. 2010. Lab-specific gene expression signatures in pluripotent stem cells. Cell Stem Cell 7(2):258-262 DOI 10.1016/j.stem.2010.06.016.

Nichols J, Smith A. 2009. Naive and primed pluripotent states. Cell Stem Cell 4(6):487-492 DOI 10.1016/j.stem.2009.05.015. 
Nichols J, Zevnik B, Anastassiadis K, Niwa H, Klewe-Nebenius D, Chambers I, Scholer H, Smith A. 1998. Formation of pluripotent stem cells in the mammalian embryo depends on the POU transcription factor Oct4. Cell 95(3):379-391 DOI 10.1016/s0092-8674(00)81769-9.

Nishimura K, Sano M, Ohtaka M, Furuta B, Umemura Y, Nakajima Y, Ikehara Y, Kobayashi T, Segawa H, Takayasu S, Sato H, Motomura K, Uchida E, Kanayasu-Toyoda T, Asashima M, Nakauchi H, Yamaguchi T, Nakanishi M. 2011. Development of defective and persistent Sendai virus vector: a unique gene delivery/expression system ideal for cell reprogramming. Journal of Biological Chemistry 286(6):4760-4771 DOI 10.1074/jbc.m110.183780.

Nishino K, Toyoda M, Yamazaki-Inoue M, Fukawatase Y, Chikazawa E, Sakaguchi H, Akutsu H, Umezawa A. 2011. DNA methylation dynamics in human induced pluripotent stem cells over time. PLOS Genetics 7(5):e1002085 DOI 10.1371/journal.pgen.1002085.

Nishishita N, Shikamura M, Takenaka C, Takada N, Fusaki N, Kawamata S. 2012. Generation of virus-free induced pluripotent stem cell clones on a synthetic matrix via a single cell subcloning in the naive state. PLOS ONE 7(6):e38389 DOI 10.1371/journal.pone.0038389.

Niwa H, Miyazaki J, Smith AG. 2000. Quantitative expression of Oct-3/4 defines differentiation, dedifferentiation or self renewal of ES cells. Nature Genetics 24:372-376.

Okano M, Bell DW, Haber DA, Li E. 1999. DNA methyltransferases Dnmt3a and Dnmt3b are essential for de novo methylation and mammalian development. Cell 99(3):247-257 DOI 10.1016/s0092-8674(00)81656-6.

Okita K, Hong H, Takahashi K, Yamanaka S. 2010. Generation of mouse-induced pluripotent stem cells with plasmid vectors. Nature Protocols 5(3):418-428 DOI 10.1038/nprot.2009.231.

Okita K, Ichisaka T, Yamanaka S. 2007. Generation of germline-competent induced pluripotent stem cells. Nature 448(7151):313-317 DOI 10.1038/nature05934.

Okita K, Matsumura Y, Sato Y, Okada A, Morizane A, Okamoto S, Hong H, Nakagawa M, Tanabe K, Tezuka K, Shibata T, Kunisada T, Takahashi M, Takahashi J, Saji H, Yamanaka S. 2011. A more efficient method to generate integration-free human iPS cells. Nature Methods 8(5):409-412 DOI 10.1038/nmeth.1591.

Okita K, Nakagawa M, Hyenjong H, Ichisaka T, Yamanaka S. 2008. Generation of mouse induced pluripotent stem cells without viral vectors. Science 322(5903):949-953

DOI 10.1126/science.1164270.

Okumura-Nakanishi S, Saito M, Niwa H, Ishikawa F. 2005. Oct-3/4 and Sox2 regulate Oct-3/4 gene in embryonic stem cells. Journal of Biological Chemistry 280(7):5307-5317 DOI 10.1074/jbc.m410015200.

Onder TT, Kara N, Cherry A, Sinha AU, Zhu N, Bernt KM, Cahan P, Marcarci BO, Unternaehrer J, Gupta PB, Lander ES, Armstrong SA, Daley GQ. 2012. Chromatin-modifying enzymes as modulators of reprogramming. Nature 483(7391):598-602 DOI 10.1038/nature10953.

Ono M, Hamada Y, Horiuchi Y, Matsuo-Takasaki M, Imoto Y, Satomi K, Arinami T, Hasegawa M, Fujioka T, Nakamura Y, Noguchi E. 2012. Generation of induced pluripotent stem cells from nasal epithelial cells using a Sendai virus vector. PLOS ONE 7(8):e42855

DOI 10.1371/journal.pone.0042855.

Osafune K, Caron L, Borowiak M, Martinez RJ, Fitz-Gerald CS, Sato Y, Cowan CA, Chien KR, Melton DA. 2008. Marked difference in differentiation propensity among human embryonic stem cell lines. Nature Biotechnology 26(3):313-315 DOI 10.1038/nbt1383.

Pappas JJ, Yang PC. 2008. Human ESC vs iPSC—Pros and Cons. Journal of Cardiovascular Translational Research 1(2):96-99 DOI 10.1007/s12265-008-9032-2. 
Park ET, Gum JR, Kakar S, Kwon SW, Deng G, Kim YS. 2008a. Aberrant expression of SOX2 upregulates MUC5AC gastric foveolar mucin in mucinous cancers of the colorectum and related lesions. International Journal of Cancer 122(6):1253-1260 DOI 10.1002/ijc.23225.

Park IH, Zhao R, West JA, Yabuuchi A, Huo H, Ince TA, Lerou PH, Lensch MW, Daley GQ. 2008b. Reprogramming of human somatic cells to pluripotency with defined factors. Nature 451(7175):141-146 DOI 10.1038/nature06534.

Patel JH, Loboda AP, Showe MK, Showe LC, McMahon SB. 2004. Analysis of genome targets reveals complex functions of MYC. Nature Reviews Cancer 4(7):562-568 DOI 10.1038/nrc1393.

Perez-Pinera P, Kocak DD, Vockley CM, Adler AF, Kabadi AM, Polstein LR, Thakore PI, Glass KA, Ousterout DG, Leong KW, Guilak F, Crawford GE, Reddy TE, Gersbach CA. 2013. RNAguided gene activation by CRISPR-Cas9-based transcription factors. Nature Methods 10(10):973-976 DOI 10.1038/nmeth.2600.

Polo JM, Anderssen E, Walsh RM, Schwarz BA, Nefzger CM, Lim SM, Borkent M, Apostolou E, Alaei S, Cloutier J, Bar-Nur O, Cheloufi S, Stadtfeld M, Figueroa ME, Robinton D, Natesan S, Melnick A, Zhu J, Ramaswamy S, Hochedlinger K. 2012. A molecular roadmap of reprogramming somatic cells into iPS cells. Cell 151(7):1617-1632 DOI 10.1016/j.cell.2012.11.039.

Rais Y, Zviran A, Geula S, Gafni O, Chomsky E, Viukov S, Mansour AA, Caspi I, Krupalnik V, Zerbib M, Maza I, Mor N, Baran D, Weinberger L, Jaitin DA, Lara-Astiaso D, Blecher-Gonen R, Shipony Z, Mukamel Z, Hagai T, Gilad S, Amann-Zalcenstein D, Tanay A, Amit I, Novershtern N, Hanna JH. 2013. Deterministic direct reprogramming of somatic cells to pluripotency. Nature 502(7469):65-70 DOI 10.1038/nature12587.

Rodda DJ, Chew JL, Lim LH, Loh YH, Wang B, Ng HH, Robson P. 2005. Transcriptional regulation of Nanog by OCT4 and SOX2. Journal of Biological Chemistry 280(26):24731-24737 DOI 10.1074/jbc.m502573200.

Rodriguez-Piza I, Richaud-Patin Y, Vassena R, Gonzalez F, Barrero MJ, Veiga A, Raya A, Izpisua-Belmonte JC. 2010. Reprogramming of human fibroblasts to induced pluripotent stem cells under xeno-free conditions. Stem Cells 28(1):36-44 DOI 10.1002/stem.248.

Roush S, Slack FJ. 2008. The let-7 family of microRNAs. Trends in Cell Biology 18(10):505-516 DOI 10.1016/j.tcb.2008.07.007.

Rowland BD, Bernards R, Peeper DS. 2005. The KLF4 tumour suppressor is a transcriptional repressor of p53 that acts as a context-dependent oncogene. Nature Cell Biology 7(11):1074-1082 DOI 10.1038/ncb1314.

Sanjana NE, Cong L, Zhou Y, Cunniff MM, Feng G, Zhang F. 2012. A transcription activator-like effector toolbox for genome engineering. Nature Protocols 7(1):171-192

DOI 10.1038/nprot.2011.431.

Scheper W, Copray S. 2009. The molecular mechanism of induced pluripotency: a two-stage switch. Stem Cell Reviews and Reports 5(3):204-223 DOI 10.1007/s12015-009-9077-x.

Scudellari M. 2016. How iPS cells changed the world. Nature 534(7607):310-312 DOI 10.1038/534310a.

Segal DJ, Meckler JF. 2013. Genome engineering at the dawn of the golden age. Annual Review of Genomics and Human Genetics 14(1):135-158 DOI 10.1146/annurev-genom-091212-153435.

Seki T, Yuasa S, Fukuda K. 2012. Generation of induced pluripotent stem cells from a small amount of human peripheral blood using a combination of activated $\mathrm{T}$ cells and Sendai virus. Nature Protocols 7(4):718-728 DOI 10.1038/nprot.2012.015.

Seki T, Yuasa S, Oda M, Egashira T, Yae K, Kusumoto D, Nakata H, Tohyama S, Hashimoto H, Kodaira M, Okada Y, Seimiya H, Fusaki N, Hasegawa M. 2010. Generation of induced 
pluripotent stem cells from human terminally differentiated circulating T cells. Cell Stem Cell 7(1):11-14 DOI 10.1016/j.stem.2010.06.003.

Seoane J, Le HV, Massague J. 2002. Myc suppression of the p21(Cip1) Cdk inhibitor influences the outcome of the p53 response to DNA damage. Nature 419(6908):729-734

DOI 10.1038/nature01119.

Shalem O, Sanjana NE, Hartenian E, Shi X, Scott DA, Mikkelson T, Heckl D, Ebert BL, Root DE, Doench JG, Zhang F. 2014. Genome-scale CRISPR-Cas9 knockout screening in human cells. Science 343(6166):84-87 DOI 10.1126/science.1247005.

Sharma A, Diecke S, Zhang WY, Lan F, He C, Mordwinkin NM, Chua KF, Wu JC. 2013. The role of SIRT6 in aging and reprogramming of human induced pluripotent stem cells. Journal of Biological Chemistry 288(25):18439-18447 DOI 10.1074/jbc.m112.405928.

Shi Y, Desponts C, Do JT, Hahm HS, Scholer HR, Ding S. 2008. Induction of pluripotent stem cells from mouse embryonic fibroblasts by Oct4 and Klf4 with small-molecule compounds. Cell Stem Cell 3(5):568-574 DOI 10.1016/j.stem.2008.10.004.

Shi Y, Inoue H, Wu JC, Yamanaka S. 2017. Induced pluripotency stem cell technology: a decade of progress. Nature Reviews Drug Discovery 16(2):115-130 DOI 10.1038/nrd.2016.245.

Si-Tayeb K, Noto FK, Sepac A, Sedlic F, Bosnjak ZJ, Lough JW, Duncan SA. 2010. Generation of human induced pluripotent stem cells by simple transient transfection of plasmid DNA encoding reprogramming factors. BMC Developmental Biology 10(1):81 DOI 10.1186/1471-213x-10-81.

Smith ZD, Meissner A. 2013. DNA methylation: roles in mammalian development. Nature Reviews Genetics 14(3):204-220 DOI 10.1038/nrg3354.

Soldner F, Hockemeyer D, Beard C, Gao Q, Bell GW, Cook EG, Hargus G, Blak A, Cooper O, Mitalipova M, Isacson O, Jaenisch R. 2009. Parkinson's disease patient-derived induced pluripotent stem cells free of viral reprogramming factors. Cell 136(5):964-977 DOI 10.1016/j.cell.2009.02.013.

Sommer CA, Stadtfeld M, Murphy GJ, Hochedlinger K, Kotton DN, Mostoslavsky G. 2009. Induced pluripotent stem cell generation using a single lentiviral stem cell cassette. Stem Cells 27(3):543-549 DOI 10.1634/stemcells.2008-1075.

Stadtfeld M, Brennand K, Hochedlinger K. 2008. Reprogramming of pancreatic $\beta$ cells into induced pluripotent stem cells. Current Biology 18(12):890-894 DOI 10.1016/j.cub.2008.05.010.

Stadtfeld M, Maherali N, Breault DT, Hochedlinger K. 2008a. Defining molecular cornerstones during fibroblast to iPS cell reprogramming in mouse. Cell Stem Cell 2(3):230-240 DOI 10.1016/j.stem.2008.02.001.

Stadtfeld M, Nagaya M, Utikal J, Weir G, Hochedlinger K. 2008b. Induced pluripotent stem cells generated without viral integration. Science 322(5903):945-949 DOI 10.1126/science.1162494.

Staerk J, Dawlaty MM, Gao Q, Maetzel D, Hanna J, Sommer CA, Mostoslavsky G, Jaenisch R. 2010. Reprogramming of peripheral blood cells into induced pluripotent stem cells. Cell Stem Cell 7(1):20-24 DOI 10.1016/j.stem.2010.06.002.

Stewart CL, Stuhlmann H, Jahner D, Jaenisch R. 1982. De novo methylation, expression, and infectivity of retroviral genomes introduced into embryonal carcinoma cells. Proceedings of the National Academy of Sciences of the United States of America 79(13):4098-4102 DOI 10.1073/pnas.79.13.4098.

Subramanyam D, Lamouille S, Judson RL, Liu JY, Bucay N, Derynck R, Blelloch R. 2011. Multiple targets of miR-302 and miR-372 promote reprogramming of human fibroblasts to induced pluripotent stem cells. Nature Biotechnology 29(5):443-448 DOI 10.1038/nbt.1862. 
Sun N, Panetta NJ, Gupta DM, Wilson KD, Lee A, Jia F, Hu S, Cherry AM, Robbins RC, Longaker MT, Wu JC. 2009. Feeder-free derivation of induced pluripotent stem cells from adult human adipose stem cells. Proceedings of the National Academy of Sciences of the United States of America 106(37):15720-15725 DOI 10.1073/pnas.0908450106.

Tada M, Takahama Y, Abe K, Nakatsuji N, Tada T. 2001. Nuclear reprogramming of somatic cells by in vitro hybridization with ES cells. Current Biology 11(19):1553-1558

DOI 10.1016/s0960-9822(01)00459-6.

Takahashi K, Tanabe K, Ohnuki M, Narita M, Ichisaka T, Tomoda K, Yamanaka S. 2007. Induction of pluripotent stem cells from adult human fibroblasts by defined factors. Cell 131(5):861-872 DOI 10.1016/j.cell.2007.11.019.

Takahashi K, Yamanaka S. 2006. Induction of pluripotent stem cells from mouse embryonic and adult fibroblast cultures by defined factors. Cell 126(4):663-676 DOI 10.1016/j.cell.2006.07.024.

Takahashi K, Yamanaka S. 2016. A decade of transcription factor-mediated reprogramming to pluripotency. Nature Reviews Molecular Cell Biology 17(3):183-193 DOI 10.1038/nrm.2016.8.

Thomson JA, Itskovitz-Eldor J, Shapiro SS, Waknitz MA, Swiergiel JJ, Marshall VS, Jones JM. 1998. Embryonic stem cell lines derived from human blastocysts. Science 282(5391):1145-1147 DOI 10.1126/science.282.5391.1145.

Tiemann U, Sgodda M, Warlich E, Ballmaier M, Scholer HR, Schambach A, Cantz T. 2011. Optimal reprogramming factor stoichiometry increases colony numbers and affects molecular characteristics of murine induced pluripotent stem cells. Cytometry Part A 79(6):426-435 DOI 10.1002/cyto.a.21072.

Tokusumi T, lida A, Hirata T, Kato A, Nagai Y, Hasegawa M. 2002. Recombinant Sendai viruses expressing different levels of a foreign reporter gene. Virus Research 86(1-2):33-38 DOI 10.1016/s0168-1702(02)00047-3.

Trounson A, DeWitt ND. 2016. Pluripotent stem cells progressing to the clinic. Nature Reviews Molecular Cell Biology 17(3):194-200 DOI 10.1038/nrm.2016.10.

Tsubooka N, Ichisaka T, Okita K, Takahashi K, Nakagawa M, Yamanaka S. 2009. Roles of Sall4 in the generation of pluripotent stem cells from blastocysts and fibroblasts. Genes to Cells 14(6):683-694 DOI 10.1111/j.1365-2443.2009.01301.x.

Urbach A, Schuldiner M, Benvenisty N. 2004. Modeling for Lesch-Nyhan disease by gene targeting in human embryonic stem cells. Stem Cells 22(4):635-641 DOI 10.1634/stemcells.22-4-635.

Utikal J, Maherali N, Kulalert W, Hochedlinger K. 2009a. Sox2 is dispensable for the reprogramming of melanocytes and melanoma cells into induced pluripotent stem cells. Journal of Cell Science 122(19):3502-3510 DOI 10.1242/jcs.054783.

Utikal J, Polo JM, Stadtfeld M, Maherali N, Kulalert W, Walsh RM, Khalil A, Rheinwald JG, Hochedlinger K. 2009b. Immortalization eliminates a roadblock during cellular reprogramming into iPS cells. Nature 460(7259):1145-1148 DOI 10.1038/nature08285.

Viswanathan SR, Daley GQ, Gregory RI. 2008. Selective blockade of microRNA processing by Lin28. Science 320(5872):97-100 DOI 10.1126/science.1154040.

Wang T, Chen K, Zeng X, Yang J, Wu Y, Shi X, Qin B, Zeng L, Esteban MA, Pan G, Pei D. 2011. The histone demethylases Jhdm1a/lb enhance somatic cell reprogramming in a vitamin C-dependent manner. Cell Stem Cell 9(6):575-587 DOI 10.1016/j.stem.2011.10.005.

Wang Y, Xu Z, Jiang J, Xu C, Kang J, Xiao L, Wu M, Xiong J, Guo X, Liu H. 2013. Endogenous miRNA sponge lincRNA-RoR regulates Oct4, NaNog, and Sox2 in human embryonic stem cell self-renewal. Developmental Cell 25(1):69-80 DOI 10.1016/j.devcel.2013.03.002. 
Warren L, Manos PD, Ahfeldt T, Loh YH, Li H, Lau F, Ebina W, Mandal PK, Smith ZD, Meissner A. 2010. Daley GQ, Brack AS, Collins JJ, Cowan C, Schlaeger TM, Rossi DJ. 2010. Highly efficient reprogramming to pluripotency and directed differentiation of human cells with synthetic modified mRNA. Cell Stem Cell 7(5):618-630 DOI 10.1016/j.stem.2010.08.012.

Warren L, Ni Y, Wang J, Guo X. 2012. Feeder-free derivation of human induced pluripotent stem cells with messenger RNA. Scientific Reports 2(1):657 DOI 10.1038/srep00657.

Wernig M, Lengner CJ, Hannah J, Lodato MA, Steine E, Foreman R, Staerk J, Markoulaki S, Jaenisch R. 2008a. A drug-inducible transgenic system for direct reprogramming of multiple somatic cell types. Nature Biotechnology 26(8):916-924 DOI 10.1038/nbt1483.

Wernig M, Zhao JP, Pruszak J, Hedlund E, Fu D, Soldner F, Broccoli V, Constantine-Paton M, Isacson O, Jaenisch R. 2008b. Neurons derived from reprogrammed fibroblasts functionally integrate into the fetal brain and improve symptoms of rats with Parkinson's disease. Proceedings of the National Academy of Sciences of the United States of America 105(15):5856-5861 DOI 10.1073/pnas.0801677105.

Wernig M, Meissner A, Foreman R, Brambrink T, Ku M, Hochedlinger K, Bernstein BE, Jaenisch R. 2007. In vitro reprogramming of fibroblasts into a pluripotent ES cell-like state. Nature 448(7151):318-324 DOI 10.1038/nature05944.

Wilmut I, Schnieke AE, McWhir J, Kind AJ, Campbell KH. 1997. Viable offspring derived from fetal and adult mammalian cells. Nature 385(6619):810-813 DOI 10.1038/385810a0.

Wobus AM, Loser P. 2011. Present state and future perspectives of using pluripotent stem cells in toxicology research. Archives of Toxicology 85(2):79-117 DOI 10.1007/s00204-010-0641-6.

Woltjen K, Michael IP, Mohseni P, Desai R, Mileikovsky M, Hamalainen R, Cowling R, Wang W, Liu P, Gertsenstein M, Kaji K, Sung HK, Nagy A. 2009. piggyBac transposition reprograms fibroblasts to induced pluripotent stem cells. Nature 458(7239):766-770 DOI 10.1038/nature07863.

Worringer KA, Rand TA, Hayashi Y, Sami S, Takahashi K, Tanabe K, Narita M, Srivastava D, Yamanaka S. 2014. The Let-7/LIN-41 pathway regulates reprogramming to human induced pluripotent stem cells by controlling expression of prodifferentiation genes. Cell Stem Cell 14(1):40-52 DOI 10.1016/j.stem.2013.11.001.

Wu SM, Hochedlinger K. 2011. Harnessing the potential of induced pluripotent stem cells for regenerative medicine. Nature Cell Biology 13(5):497-505 DOI 10.1038/ncb0511-497.

Xiao A, Wang Z, Hu Y, Wu Y, Luo Z, Yang Z, Zu Y, Li W, Huang P, Tong X, Zhu Z, Lin S, Zhang B. 2013. Chromosomal deletions and inversions mediated by TALENs and CRISPR/Cas in zebrafish. Nucleic Acids Research 41(14):e141 DOI 10.1093/nar/gkt464.

Yakubov E, Rechavi G, Rozenblatt S, Givol D. 2010. Reprogramming of human fibroblasts to pluripotent stem cells using mRNA of four transcription factors. Biochemical and Biophysical Research Communications 394(1):189-193 DOI 10.1016/j.bbrc.2010.02.150.

Yamaguchi S, Hirano K, Nagata S, Tada T. 2011. Sox2 expression effects on direct reprogramming efficiency as determined by alternative somatic cell fate. Stem Cell Research 6(2):177-186 DOI 10.1016/j.scr.2010.09.004.

Yamanaka S. 2007. Strategies and new developments in the generation of patient-specific pluripotent stem cells. Cell Stem Cell 1(1):39-49 DOI 10.1016/j.stem.2007.05.012.

Yamanaka S. 2009. Elite and stochastic models for induced pluripotent stem cell generation. Nature 460(7251):49-52 DOI 10.1038/nature08180.

Yang P, Wang Y, Chen J, Li H, Kang L, Zhang Y, Chen S, Zhu B, Gao S. 2011. RCOR2 is a subunit of the LSD1 complex that regulates ESC property and substitutes for Sox2 in reprogramming somatic cells to pluripotency. Stem Cells 29(5):791-801 DOI 10.1002/stem.634. 
Yoshida Y, Takahashi K, Okita K, Ichisaka T, Yamanaka S. 2009. Hypoxia enhances the generation of induced pluripotent stem cells. Cell Stem Cell 5(3):237-241

DOI 10.1016/j.stem.2009.08.001.

Yu J, Hu K, Smuga-Otto K, Tian S, Stewart R, Slukvin II, Thomson JA. 2009. Human induced pluripotent stem cells free of vector and transgene sequences. Science 324(5928):797-801 DOI 10.1126/science.1172482.

Yu J, Vodyanik MA, Smuga-Otto K, Antosiewicz-Bourget J, Frane JL, Tian S, Nie J, Jonsdottir GA, Ruotti V, Stewart R, Slukvin II, Thomson JA. 2007. Induced pluripotent stem cell lines derived from human somatic cells. Science 318(5858):1917-1920 DOI 10.1126/science.1151526.

Zhang W, Geiman DE, Shields JM, Dang DT, Mahatan CS, Kaestner KH, Biggs JR, Kraft AS, Yang VW. 2000. The gut-enriched Kruppel-like factor (Kruppel-like factor 4) mediates the transactivating effect of $\mathrm{p} 53$ on the $\mathrm{p} 21^{\text {WAF/Cip } 1}$ promoter. Journal of Biological Chemistry 275(24):18391-18398 DOI 10.1074/jbc.c000062200.

Zhao Y, Yin X, Qin H, Zhu F, Liu H, Yang W, Zhang Q, Xiang C, Hou P, Song Z, Liu Y, Yong J, Zhang P, Cai J, Liu M, Li H, Li Y, Qu X, Cui K, Zhang W, Xiang T, Wu Y, Zhao Y, Liu C, Yu C, Yuan K, Lou J, Ding M, Deng H. 2008. Two supporting factors greatly improve the efficiency of human iPSC generation. Cell Stem Cell 3(5):475-479 DOI 10.1016/j.stem.2008.10.002.

Zhou W, Freed CR. 2009. Adenoviral gene delivery can reprogram human fibroblasts to induced pluripotent stem cells. Stem Cells 27(11):2667-2674 DOI 10.1002/stem.201.

Zhou H, Wu S, Joo JY, Zhu S, Han DW, Lin T, Trauger S, Bien G, Yao S, Zhu Y, Siuzdak G, Scholer HR, Duan L, Ding S. 2009. Generation of induced pluripotent stem cells using recombinant proteins. Cell Stem Cell 4(5):381-384 DOI 10.1016/j.stem.2009.04.005.

Zou J, Maeder ML, Mali P, Pruett-Miller SM, Thibodeau-Beganny S, Chou BK, Chen G, Ye Z, Park IH, Daley GQ, Porteus MH, Joung JK, Cheng L. 2009. Gene targeting of a disease-related gene in human induced pluripotent stem and embryonic stem cells. Cell Stem Cell 5(1):97-110 DOI 10.1016/j.stem.2009.05.023. 